\title{
Journal of Animal Ecology
}

\section{Land use alters trophic redundancy and resource flow through stream food webs}

\begin{tabular}{|r|l|}
\hline Journal: & Journal of Animal Ecology \\
\hline Manuscript ID & JAE-2018-00670.R2 \\
\hline Danuscript Type: & Research Article \\
\hline Author: & 08-Dec-2018 \\
\hline & $\begin{array}{l}\text { Price, Elliott; University of Liverpool School of Environmental Sciences, } \\
\text { Earth, Ocean and Ecological Sciences } \\
\text { Sertić Perić, Mirela; Sveuciliste u Zagrebu Bioloski odsjek } \\
\text { Romero, Gustavo; State university of Campinas, Animal Biology } \\
\text { Kratina, Pavel; Queen Mary University of London, School of Biological } \\
\text { and Chemical Sciences }\end{array}$ \\
\hline Key-words: & $\begin{array}{l}\text { Bottom-up control, Diet estimates, Energy flow, Stable isotope analysis, } \\
\text { Trophic redundancy, Urban streams }\end{array}$ \\
\hline &
\end{tabular}

\section{SCHOLARONE Manuscripts}


1 Land use alters trophic redundancy and resource flow through stream 2 food webs Elliott L. Price ${ }^{1, *}$, Mirela Sertić Perićn ${ }^{2}$, Gustavo Q. Romero ${ }^{3}$ \& Pavel Kratina ${ }^{1, *}$

$6{ }^{1}$ School of Biological and Chemical Sciences, Queen Mary University of London, Mile End 7 Road, London, E1 4NS, United Kingdom

$8{ }^{2}$ University of Zagreb, Faculty of Science, Department of Biology, Rooseveltov trg 6, 9 Zagreb, Croatia

$10{ }^{3}$ Departamento de Biologia Animal, Universidade Estadual de Campinas (UNICAMP), 11 Campinas, Brazil

13 Current address: Department of Earth, Ocean and Ecological Sciences, University of 14 Liverpool, Liverpool, L69 3BX, United Kingdom

*Corresponding Authors: elliott.price@liverpool.ac.uk,p.kratina@qmul.ac.uk

Running Title: Urbanisation modulates food webs

21 Keywords: Bottom-up control, diet estimates, energy flow, stable isotope analysis, trophic 22 redundancy, urban streams. 


\section{Abstract}

1. The changes to physical and chemical ecosystem characteristics as a response to pervasive and intensifying land use have the potential to alter the consumer-resource interactions and to rewire the flow of energy through entire food webs.

2. We investigated these structural and functional properties of food webs in stream ecosystems distributed across woodland, agricultural and urban areas in the Zagreb region of

Croatia. We compared resource availability and consumer diet composition using stable isotope mixing models and tested how the isotopic variance of basal resources, primary consumers, macroinvertebrate predators, and other food-web characteristics change with different land use types.

3. Combination of increased loading and altered composition of nutrients, lower water discharge and higher light availability at urban sites likely promoted the contribution of aquatic macrophytes to diets of primary consumers. Macroinvertebrate predators shifted their diet, relying more on active filterers at urban sites relative to woodland and agricultural sites. Urban food webs also had lower trophic redundancy (i.e. fewer species at each trophic level) and a more homogenised energy flow from lower to higher trophic levels. There was no effect of land use on isotopic variation of basal resources, primary consumers or macroinvertebrate predators, but all these trophic groups at urban and agricultural sites were ${ }^{15} \mathrm{~N}$-enriched relative to their counterparts in woodland stream food webs.

4. The physical and chemical ecosystem characteristics associated with intensive land use altered the resource availability, trophic redundancy and the flow of energy to other trophic levels, with potentially negative consequences for community dynamics and ecosystem functioning. These empirical findings indicate that reducing nutrient pollution, 
46 agricultural runoffs and maintaining riparian vegetation can mitigate the impacts of land use 47 on structure and function of stream ecosystems. 


\section{Introduction}

Intensive land use represents the leading threat to Earth's ecosystems and biodiversity (Sala et al., 2000; Vitousek, Mooney, Lubchenco, \& Melillo, 1997). In particular, urbanization is profoundly altering abiotic and biotic ecosystem characteristics and it has become a leading cause of population extirpation across a wide range of species (Clergeau, Croci, Jokimäki, Kaisanlahti-Jokimäki, \& Dinetti, 2006; McKinney, 2006). Similarly, industrial-scale agriculture and associated changes to nutrient cycling increase rates of species extinctions through dominance of few superior competitors that often reduce species richness and biodiversity (Carpenter, Cole, Kitchell, \& Pace, 1998; Chapin et al., 2000; Guignard et al., 2017). However, the processes that underpin the structure and function of ecological communities may differ substantially among ecosystems influenced by different land use. Although the impacts of severe degradation, reduction and loss of habitats caused by intensive land use activities are widespread among taxonomic groups and ecosystem types, these impacts are particularly pervasive in freshwater ecosystems (Ormerod, Dobson, Hildrew, \& Townsend, 2010; Strayer \& Dudgeon, 2010).

The initial responses to land use changes may occur at a level of trophic interactions, resource use, and feeding behaviour of primary and secondary consumers (Alley, 1982; Beaugrand, Mackas, \& Goberville, 2013). Consumers can buffer changes in the resources availability via feeding plasticity (Friberg \& Jacobsen, 1994; Zah, Burgherr \& Bernasconi 2001), shifting their feeding preferences to new resources in response to habitat disturbance (Zah, Burgherr \& Bernasconi 2001). High functional redundancy (i.e. large proportion of species with similar trophic ecologies) allows an ecosystem to maintain its function despite some taxa going locally extinct. Conversely, low functional redundancy usually weakens ecosystem resilience to stressors such as climate and land use changes (Cardinale, Palmer \& Collins 2002). In aquatic systems, the ecosystem resilience to environmental change can also 
be indicated by the relative contribution of allochthonous to autochthonous resources to food webs (Recalde, Postali, \& Romero 2016). For instance, a stream food web with a high dependence on allochthonous material may undergo a disruptive shift in nutrient budgets if the surrounding land became urbanized and the vegetation in the catchment is reduced (Finlay, Khandwala, \& Power 2002). On the other hand, autochthonous primary producers can provide a better nutritional resource than terrestrial litter (Brett, Kainz, Taipale, \& Seshan, 2009; Junker \& Cross, 2014; Thorp \& Delong, 2002), leading to higher biomass production of top consumers (Karlsson et al., 2015). Such shifts toward resources with high nutritional quality in streams with open canopy, in combination with higher transfer efficiency of these resources to primary consumers, can elongate food chains in comparison to woodland streams with closed canopy cover (Lau, Leung, \& Dudgeon, 2009).

Consequently, the impact of different land use on the taxonomic and nutritional composition of basal resources can cascade to higher trophic levels, altering the structure and flow of energy through the entire food web (De Castro et al., 2016; Kratina \& Winder, 2015; Layman, John, Peyer, \& Allgeier, 2007).

Recent advances in stable isotope analyses allow us to estimate community-wide characteristics such as variety of resources, trophic diversity, trophic redundancy and other metrics closely related to resource use, diet specialization and degree of omnivory (Layman, Arrington, Montaña, \& Post, 2007; Nielsen, Clare, Hayden, Brett, \& Kratina, 2018). These analyses often rely on quantifying existing differences in the nitrogen and carbon stable isotope composition of food resources (Newsome, Rio, Bearhop, \& Phillips, 2007; Rader et al., 2017). Stable isotope analyses can determine the maximum trophic position through comparing nitrogen stable isotope ratios of all food web components and disentangle the pathways of energy flow from primary producers through to primary consumers and predators through a comparison of carbon stable isotope ratios. However, the application of 
isotopic metrics to understand how ecological communities respond to different types of land use are scarce and the impacts of human activities in urban zones are rarely compared to the impacts in agricultural and woodland areas.

To understand the community-level impacts of different types of land use, we compared the resource availability and composition, variance in isotopic composition of macroinvertebrate consumers and the resilience-related food-web properties in urban, agricultural and woodland stream habitats. We hypothesised that stream sites with stronger urban and agricultural influences show: (i) shifts in basal resource availability, characterized by $\delta^{13} \mathrm{C}$ values that change minimally with trophic transfer, but can vary substantially across different resource types (McCutchan Jr, Lewis Jr, Kendall, \& McGrath, 2003; Newsome, Rio, Bearhop, \& Phillips, 2007); (ii) an increased contribution of aquatic (autochthonous) resources relative to terrestrial (allochthonous) resources, which is reflected in the stable isotope values of primary consumers; (iii) higher $\delta^{15} \mathrm{~N}$ values of macroinvertebrate consumers (as a consequence of greater in-stream additions of urban wastes that usually increase basal resource-stable isotope values), or a longer food chain revealed by predators with high $\delta^{15} \mathrm{~N}$ values relative to basal resources; and (iv) fewer basal resources being exploited and lower functional (i.e. trophic) redundancy of macroinvertebrate assemblages shown through fewer species occupying a similar position in isotopic-niche space. Such empirical evidence could improve our understanding of the land use effects on the flow of energy through food webs and provide deeper mechanistic insights into the functioning of ecosystems in humanmodified landscapes. 


\section{Materials and methods}

\section{Study sites}

122 We collected samples of macroinvertebrates and their potential food resources from five streams in the region of Zagreb, Croatia (Fig. 1): Vrapčak (V), Kustošak (K), Veliki potok

124 (VP), Bliznec (B) and Trnava (T). Zagreb is the largest city of Croatia with a population of approximately 800,000 , representing the Croatian centre of economic and municipal activities. The stream network of Zagreb consists of 31 low-order streams flowing from the less human-impacted regions concentrated at the north of the city, through both agricultural and urban downstream areas where they are increasingly affected by anthropogenic (i.e. residential, municipal, industrial, agricultural) activities and physical modifications. Whereas agricultural land use prevails in the eastern part of the region, a high-density residential, municipal and industrial land use dominates the central and western part of the Zagreb area (Fig. 1). The streams flow into the River Sava, a tributary to the second largest river in Europe, the Danube River. The upper reaches of the five focal streams are situated within the forested area of Medvednica Nature Park to the north/northwest of Zagreb. The sampling sites were classified as woodland $(n=5)$, agricultural $(n=4)$ or urban $(n=6)$ based on the surrounding land use and proximity to the city centre. The woodland sites were characterised by a dense canopy cover, low light availability and sparse in-stream vegetation. However, there were dense stands of in-stream vegetation in the open canopy at urban and agricultural sites characterized by scarce riparian vegetation (mostly C4-grasses). The elevation of woodland sites ranged from 206-395 m a.s.1., agricultural sites from 132-217 m a.s.1., and urban sites from 155-161 m a.s.l. (Fig. 1). The physical, chemical and biological characteristics were measured at each location between late April and early May 2017. 
Physical and chemical stream parameters were measured to identify environmental

characteristics that have the potential to alter macroinvertebrate diets, isotopic composition, and food web structure across the study sites (Table S1). The average stream width, depth and flow velocity (flow velocity meter P600, Dostman electronic $\mathrm{GmbH}$ ) at the three crosssectional stream areas were measured, to give an estimate of the stream discharge. We also measured in situ water temperature $\left({ }^{\circ} \mathrm{C}\right)$, dissolved oxygen concentration $\left(\mathrm{mg} \mathrm{L}^{-1}\right)$ and saturation (\%) using oximeter OXI 96 (WTW, Germany), conductivity $\left(\mu \mathrm{S} \mathrm{cm}^{-1}\right)$ using conductivity meter Hach Sension 5 (Hach Company, USA), and pH using pH-meter 330i (WTW, Germany). At each site, an additional 1-L water sample was taken for laboratory analysis of the chemical parameters that could not be measured in situ. Alkalinity and total water hardness (TWH) were measured to describe the amount of calcium or magnesium carbonate dissolved in water. Alkalinity measures the amount of negative carbonate $\left(\mathrm{CO}_{3}{ }^{2-}\right)$ and bicarbonate $\left(\mathrm{HCO}_{3}^{-}\right)$ions, while water hardness describes the amount of positive calcium $\left(\mathrm{Ca}^{2+}\right)$ and magnesium $\left(\mathrm{Mg}^{2+}\right)$ ions. Alkalinity, total water hardness, and concentrations of nitrite, nitrate and orthophosphates were determined using the respective standardized methods described by APHA (1985). Total chemical oxygen demand (COD), used to assess the content of dissolved organic matter in water, was determined following the procedure in Deutsches Institut für Normung (1986).

\section{Consumer and resource sampling and processing}

We collected macroinvertebrates using a kick and sweep sampling method by disturbing the stream bed with a kicking action and using a benthic hand net (250- $\mu \mathrm{m}$ mesh size), ensuring that individuals from all microhabitats were represented in each sample. From the samples collected at each site, we immediately separated predatory species (to prevent predation) and 
all individuals were manually placed in containers filled with clean stream water and refrigerated at $4{ }^{\circ} \mathrm{C}$ for 24 hours in order to empty their guts. We identified all macroinvertebrate individuals to the lowest possible taxonomic resolution, mainly genus (Table S2). We have sampled 2-20 individuals from each of the dominant taxa (depending on body size) and there were $9.4 \pm 1.03$ dominant taxa (mean \pm SE) per site (Table S1). A total of 28 macroinvertebrate taxa from the 15 study sites were classified as non-predatory primary consumers, and 19 taxa were classified as predators. Based on their dietary preferences and following Moog (2002), we further classified the non-predatory primary consumers into five functional feedings groups. These functional feedings groups (FFGs) included detritivores, shredders, grazers, passive filterers, and active filterers. Because this method characterises each FFG as proportional contributions to a macroinvertebrate feeding function, each taxon was assigned to the FFG with the greatest contribution to its diet. For the subsequent analyses, we estimated dietary contributions of each predatory taxa at each site to yield multiple estimates at each site. The same method was applied to individual functional groups in the primary consumer diet estimates.

Potential dietary items from both allochthonous and autochthonous resources, i.e. periphyton separated from associated filamentous algae; particulate organic matter including leaf litter and other coarse particulate organic matter ( $\mathrm{CPOM}$ - particles $>1 \mathrm{~mm}$ in diameter), as well as fine particulate organic matter (FPOM - particles $0.45 \mu \mathrm{m}-1 \mathrm{~mm}$ in diameter), moss, aquatic and terrestrial macrophytes were collected at each site and stored in separate falcon tubes or polythene plastic bags. Terrestrial vegetation was sampled within a two-metre riparian zone from the stream edge. The finest organic matter fraction (FPOM) was collected directly into the falcon tube from slow-flowing areas at the edge of each stream and concentrated by repetitive sieving (250- $\mu \mathrm{m}$ mesh size). In the laboratory, we manually removed animals and coarse minerals from the FPOM samples, to avoid the potential 
interference among stable isotope ratio values. Periphyton was brushed off randomly selected rocks (with at least $50 \%$ coverage of biofilm) and subjected to manual exclusion of small invertebrates and detritus that might contaminate the samples and affect the $\delta^{15} \mathrm{~N}$ and $\delta^{13} \mathrm{C}$ values of the biofilm. Two replicates of periphyton were processed for the respective content of chlorophyll- $a\left(\mathrm{Chl} a, \mu \mathrm{g} \mathrm{cm} \mathrm{cm}^{-2}\right)$ following the ethanol extraction procedure of Nusch (1980). All collected resource and macroinvertebrate samples were stored at $-80^{\circ} \mathrm{C}$ and then dried at $60^{\circ} \mathrm{C}$ until processed for isotope analysis.

\section{Stable isotope analysis}

For the isotope analysis of the larger predatory taxa (e.g., Heteroptera, Odonata, Plecoptera), 2-5 individuals were used, whereas for the analysis of the smaller taxa (e.g., Chironomidae, Simuliidae, Baetidae), at least ten individuals were pooled. In total, we analysed 359 invertebrate samples for carbon $\left(\delta^{13} \mathrm{C}\right)$ and nitrogen $\left(\delta^{15} \mathrm{~N}\right)$ stable isotope ratios.

Dried samples were grounded to a fine powder and stored in plastic tubes. Aliquots of $0.8 \pm 0.05 \mathrm{mg}$ (for invertebrates) and $2.5 \pm 0.05 \mathrm{mg}$ (for resources) were placed in $8 \times 5 \mathrm{~mm}$ tin capsules and analyzed by CF-IRMS (Sercon Integra 2 Stable Isotope Analyser, Crewe, UK). Carbon $\left(\delta^{13} \mathrm{C}\right)$ and nitrogen $\left(\delta^{15} \mathrm{~N}\right)$ stable isotope ratios were calculated as $\left[\left(R_{\text {sample }} / R_{\text {standard }}\right)-1\right] \times 1000 \%$, where $R$ is the ratio of heavy to light isotope, $R_{\text {sample }}$ is from the sample, and $\mathrm{R}_{\text {standard }}$ is the international standard value. The isotopic standards were atmospheric air for nitrogen and PeeDee belemnite for carbon. Sercon software automatically corrected the delta values for the effects of drift between reference material combustions. Because lipids are depleted in ${ }^{13} \mathrm{C}$, they can bias the $\delta^{13} \mathrm{C}$ values of a bulk sample relative to the variation in lipid content between organisms (Perkins et al., 2013; Post et al., 2007). To account for variable lipid contents in animal and plant tissues, we measured the total $\mathrm{C}$ and $\mathrm{N}$ 
content of each sample using CF-IRMS, and then applied lipid-correction models to stable isotope data as described in McConnaughey \& McRoy (1979).

\section{Statistical analyses}

222 In order to estimate the effect of land use on the resource flow through the stream food web, we employed a SI (stable isotope) mixing model in the R package MixSIAR (Stock \& Semmens, 2013) and estimated the proportional contribution of different food sources to the diets of macroinvertebrate consumers. For each site, separate SI mixing models were used to estimate dietary contributions of basal resources to primary consumers, and of prey to predators. These estimates were derived from contrasts in stable isotope values between dietary resources, and the consequent fractionation of the heavier isotope upon consumption (Jackson, Inger \& Parnell 2011; Parnell et al., 2013). Because the trophic enrichment factors (TEF) vary across a range of environmental characteristics (McCutchan Jr, Lewis Jr \& Kendall 2003; Vanderklift \& Ponsard, 2003), we calculated our own FFG-specific TEF values based on our data as described in Caut et al., (2009). These were $0.98 \pm 0.29 \%$ (for ${ }^{13} \mathrm{C}$ ) and $1.82 \pm 1.27 \%$ (for ${ }^{15} \mathrm{~N}$ ) for the predator SI mixing models, and we averaged the calculated TEF values of individual primary consumer FFGs to yield a single value of $0.94 \pm$ $0.33 \%$ ( $\left({ }^{13} \mathrm{C}\right)$ and $1.95 \pm 1.27 \%$ ( $\left.{ }^{15} \mathrm{~N}\right)$ for the primary consumer SI mixing models.

To increase the SI mixing model's performance, we pooled the basal resources for the primary consumer SI mixing models into three ecologically similar groups: LAR - lower aquatic resources (periphyton, FPOM, filamentous algae), HAR - higher aquatic resources (aquatic moss, submerged and emergent aquatic macrophytes) and terrestrial resources (CPOM including leaf litter, terrestrial macrophytes) (Brett, 2014; Nielsen et al., 2018; Phillips et al., 2014). Submerged aquatic macrophytes live entirely beneath the water surface, 
whereas emergent plants are rooted in the stream bottom, but have parts projecting above the water surface. The potential prey taxa for the predator SI mixing model were classified into five functional feeding groups as shredders, grazers, detritivores, passive filterers and active filterers. Prior to the analysis, we used MANOVA to show that the individual prey groups (Wilks' lambda $=0.391, \mathrm{P}<0.001)$ and resource groups $($ Wilks' lambda $=0.808, \mathrm{P}<0.001)$ differ in their nitrogen $\left(\delta^{15} \mathrm{~N}\right)$ and carbon $\left(\delta^{13} \mathrm{C}\right)$ stable isotope ratios. The results of the SI mixing models were used to compare the contribution of each resource to its consumers across the three land use types by carrying out a MANOVA and then employing one-way bootstrapped analyses of variance (ANOVAs), with 1000 iterations. The significance was conservatively assessed with Bonferroni adjustments of alpha values. For this analysis, we used the functions boot and ran.gen from the boot package in R.

We used the R package SIBER to estimate an isotopic variance of predators, their potential prey (primary consumers), basal resources and two functional feeding groups (detritivores and grazers) that were common at the majority of sites (Table S3). We estimated isotopic variance based on multivariate, ellipse-based metric (SEAc, $\%^{2}{ }^{2}$ ), which is robust to small and unequal sample sizes (Jackson, Inger \& Parnell 2011). Moreover, we calculated the mean nitrogen $\left(\delta^{15} \mathrm{~N}\right)$ and carbon $\left(\delta^{13} \mathrm{C}\right)$ stable isotope ratios for each of these groups. All these metrics were calculated at the site level, to yield single site-based estimates. We also calculated four community-wide characteristics using the carbon and nitrogen stable isotope ratios for all macroinvertebrate taxa present at individual sites (Table S4): (i) mean nearest neighbour distance in isotopic niche space (MNND), indicating the resilience of the food web to environmental change through trophic redundancy (i.e. several functional groups at each trophic level); (ii) standard deviation of the nearest neighbour distance in the isotopic niche space (SDNND), indicating the uniformity of isotopic signature within groups, providing a further estimate of food web stability; (iii) $\delta^{15} \mathrm{~N}$ and (iv) $\delta^{13} \mathrm{C}$ ranges, reflecting the variety of 
trophic levels and basal resources that are exploited as a food source by the macroinvertebrate assemblages (Jackson, Inger \& Parnell 2011; Layman, Arrington \& Montaña 2007; Parnell et al., 2013). Finally, we estimated the length of the food chain as a difference in nitrogen stable isotope ratios between a consumer with the highest $\delta^{15} \mathrm{~N}$ signature and a basal resource with the lowest $\delta^{15} \mathrm{~N}$ signature. We then applied the linear mixed effects model (LME) to test whether these characteristics differ among the three land use types. We treated individual site as a random factor to account for non-measured (random) variation among the sites (Pinheiro \& Bates, 2000).

Finally, we analysed the impact of key physico-chemical characteristics (Fig. S1a and b) associated with the different land use types on the isotopic food-web metrics. To reduce the potential for multicollinearity among the physico-chemical characteristics, we applied a Principal Component Analysis (PCA). The axis that explained the most variation in the data (PC1; Table S5) was used as a predictor of the food-web metrics using the linear mixed effects model (LMEs); PC1 was a fixed factor and the individual site was a random factor. All statistical analyses were performed using the language environment $\mathrm{R}$ version 3.2.2 ( $\mathrm{R}$ Development Core Team, 2015).

\section{Results}

Resource flow through food webs

We surveyed 47 macroinvertebrate taxa (Table S2). Woodland sites were dominated by Ephemeroptera (37\% of the taxa), agricultural sites were dominated by the family Chironomidae (40\% taxa), whereas urban sites were dominated by family Simuliidae (40\% taxa). 

consumers at either agricultural or woodland sites (bootstrapped ANOVA, $\mathrm{t}=20.7, \mathrm{P}=0.03$,

Fig. 2a). In contrast, terrestrial resources and lower LARs did not differ in their relative contributions to the diets of primary consumer among the three land use types (terrestrial: $t=$ to the diets of macroinvertebrate predators (MANOVA; Wilks' lambda $=0.38, \mathrm{P}=0.009$, Fig. 2b). This effect was mostly driven by active filterers that were not found at either agricultural or woodland sites and therefore contributed less to predator diets at those sites (bootstrapped ANOVA, $\mathrm{t}=3.5, \mathrm{P}=0.02$, Fig. $2 \mathrm{~b}$ ).

Isotopic variance and food-web metrics

The land use type had no effect on the isotopic variation (SEAc) of basal resources (LME, $F_{2}$, ${ }_{12}=2.80, P=0.100$; Fig. 3a), potential prey (LME, $F_{2,12}=0.53, P=0.601 ;$ Fig. $\left.3 b\right)$, or macroinvertebrate predators (LME, $\mathrm{F}_{2,9}=0.05, \mathrm{P}=0.948$; Fig. $3 \mathrm{c}$ ). However, there was a strong effect of land use on the mean $\delta^{15} \mathrm{~N}$ of basal resources $\left(\mathrm{LME}, \mathrm{F}_{2,12}=6.83, \mathrm{P}=0.011\right.$; Fig. 4a), potential prey (LME, $F_{2,12}=10.46, P=0.002$; Fig. $4 b$ ), and macroinvertebrate predators (LME, $\mathrm{F}_{2,9}=21.64, \mathrm{P}<0.001$; Fig. $4 \mathrm{c}$ ). All trophic groups at agricultural and urban sites were enriched in $\delta^{15} \mathrm{~N}$ relative to those at woodland sites (Fig. 4). There was no effect of 312 land use on the mean $\delta^{13} \mathrm{C}$ of resources, potential prey or predators (Table S6). The effect of land use type on the isotopic variation (Fig. S2), $\delta^{15} \mathrm{~N}$, and $\delta^{13} \mathrm{C}$ of detritivores and grazers 
closely matched the effects found for predators and prey, except for grazers being more enriched in $\delta^{13} \mathrm{C}$ at agricultural and urban sites (Table S6). lower resilience) at urban sites than at agricultural and woodland sites (LME; $F_{2,12}=4.51, P$

$318=0.035$ ). The standard deviation of nearest neighbour distance (SDNND) was marginally more uniform at urban sites compared to agricultural and woodland sites ( $\mathrm{LME} ; \mathrm{F}_{2,12}=3.73$, $\mathrm{P}=0.055)$. However, there was no effect of land use on the $\delta^{15} \mathrm{~N}$ range $\left(\mathrm{LME} ; \mathrm{F}_{2,12}=2.35, \mathrm{P}\right.$ $=0.137)$ and $\delta^{13} \mathrm{C}$ range $\left(\mathrm{LME} ; \mathrm{F}_{2,12}=0.59, \mathrm{P}=0.570\right)$ of macroinvertebrates or on the length of the food chain ( $\left.\mathrm{LME} ; \mathrm{F}_{2,12}=1.22, \mathrm{P}=0.330\right)$. orthophosphate were all positively correlated with the PC1 axis, whereas discharge was negatively correlated with PC1 (Fig. S1a, Table S5). Temperature, pH, and chlorophyll- $a$ and $\mathrm{O}_{2}$ concentrations were positively correlated with the PC2 axis (explaining 15.5\% of the variation; Fig. S1a; Table S5). PCA illustrated the environmental differences among sites according to the water physico-chemical characteristics (Fig. S1a and b). PCA aligned most woodland and agricultural sites along a gradient of increasing discharge. Urban sites were mostly aligned along gradients of increasing conductivity, total water hardness, nutrient, chlorophyll- $a$, oxygen concentrations, $\mathrm{pH}$ and water temperature (Fig. S1a). There was a significant positive relationship between PC1 and the measure of trophic redundancy $(\mathrm{MNND})\left(\mathrm{LME} ; \mathrm{F}_{1,13}=16.10, \mathrm{P}=0.002\right.$, Fig. 5a), $\mathrm{PC} 1$ and the standard 336 deviation of niche measures (SDNND) (LME; $\mathrm{F}_{1,13}=8.95, \mathrm{P}=0.010$, Fig $5 \mathrm{~b}$ ), and between $337 \mathrm{PC} 1$ and the mean $\delta^{15} \mathrm{~N}\left(\mathrm{LME} ; \mathrm{F}_{1,13}=9.30, \mathrm{P}=0.009\right.$, Fig. $\left.5 \mathrm{c}\right)$. However, there was no 
relationship between $\mathrm{PC} 1$ and the $\delta^{15} \mathrm{~N}$ range (LME; $\mathrm{F}_{1,13}=2.58, \mathrm{P}=0.132$, Fig $5 \mathrm{~d}$ ) or between PC2 and any of the food-web metrics (Table S7).

\section{Discussion}

Whereas previous work has focused on the effect of morphological habitat features on the functioning of urban streams (Walsh et al., 2005), we demonstrate that changes to the physical and chemical characteristics in urban and agricultural zones shift the composition and availability of resources for aquatic consumers, and alter the flow of energy through the entire stream food web. The changes in physical, chemical and biological characteristics associated with intensive land use resulted in higher $\delta^{15} \mathrm{~N}$ values of stream communities, reduced trophic redundancy (MNND), and increased omnivorous feeding (as suggested by similar $\delta 15 \mathrm{~N}$ values between macroinvertebrate predators and primary consumers) and niche uniformity (SDNND). These findings improve the mechanistic understanding of community structure and function under the influence of intensive land use.

The changes in diets of primary consumers and predators in response to composition of resources across different land use indicate strong bottom-up control of macroinvertebrate communities. Such bottom-up control has been reported in various freshwater (Kiffney, Buhle, Naman, Pess, \& Klett, 2014; Shurin, Clasen, Greig, Kratina, \& Thompson, 2012), marine (Capuzzo et al., 2017) and terrestrial (Halvorson, Fuller, Entrekin, Scott, \& EvansWhite, 2018; Lister \& Garcia, 2018) ecosystems. Our results show that the bottom-up effects of land use may extend beyond individual consumer-resource interactions, and cascade to the structure of the entire food web. The positive relationship between the standard deviation of niche measures and the $\mathrm{PC} 1$ axis characterised by nutrient inputs suggests that there are less diverse dietary resources available to consumers, and more homogeneous pathways of energy 
flow to the upper trophic positions at the sites with high nutrient load and lower discharge.

Trophic redundancy among all macroinvertebrate taxa was highest, suggesting more complex food webs (Cucherousset \& Villéger, 2015), at woodland and agricultural sites with low levels of nutrients and high discharge. In contrast, the urban sites with high nutrient loading and lower discharges were characterised by having lower trophic redundancy and a more homogenised energy flow as indicated by higher MNND and SDNND values, respectively. Local extinctions in ecosystems with low trophic redundancy can lead to a collapse of a functional group (Mason, Mouillot \& Graham 2013) and negatively affect the functioning of the entire ecosystem (Heilpern, Weeks, \& Naeem, 2018; Vinebrooke et al., 2004; Wallace \& Webster, 1996). The nitrogen stable isotope ratios were strongly influenced by catchment land use. In particular, all trophic groups had higher $\delta^{15} \mathrm{~N}$ values along an increased urban and agricultural influence, in agreement with other studies (Baumgartner \& Robinson, 2017; Pastor et al., 2014). Similar $\delta^{15} \mathrm{~N}$ enrichment of macroinvertebrate consumers can indicate longer food chains in habitats with higher influence of autochthonous resources of higher nutritional quality (Lau et al., 2009; Junker \& Cross, 2014). However, there was no support for longer food chains at urban or agricultural sites, potentially due to the weaker influence of productivity in smaller ecosystems (Ward \& Mccann, 2017). Enrichment of basal resources (Chen, Mcgowan, Zeng, Xu, \& Yang, 2017; Cole et al., 2004) and stream organisms (Harrington, Kennedy, Chamberlain, Blum, \& Folt, 1998) in ${ }^{15} \mathrm{~N}$ has been also linked to higher nitrate input (Bergfur, Johnson, Sandin, \& Goedkoop, 2009) and can be caused by sewage-sourced nitrogen pollution and greater inputs of polycyclic aromatic hydrocarbons (Saito et al., 2008). Whereas the natural and fertilizer sources of nitrogen are generally depleted in ${ }^{15} \mathrm{~N}$ (Risk, Lapointe, Sherwood, \& Bedford, 2009), the sewage derived nitrogen inputs are generally enriched in ${ }^{15} \mathrm{~N}$ because of the preferential use of the lighter isotope by 
bacteria during denitrification (Heaton, 1986). The sewage pollution in combination with low water discharge might have also contributed to the lower trophic redundancy of macroinvertebrates in some urban sites (Coors \& De Meester, 2008; Vinebrooke et al., 2004).

The similar $\delta^{15} \mathrm{~N}$ values between macroinvertebrate predators and primary consumers may be driven by predators feeding predominantly on prey with lower $\delta^{15} \mathrm{~N}$ signature. Some predators and primary consumers can be omnivorous, which may increase $\delta^{15} \mathrm{~N}$ for primary consumers or reduce $\delta^{15} \mathrm{~N}$ for predators. Moreover, the basal resources at our sites are composed of diverse groups that widely vary in $\delta^{15}$ N.Furthermore, the urban and agricultural sites have rapidly changing environmental conditions and rapid shifts in the composition of basal resources over time (E. L. Price and M. Sertić Perić, personal observation, February 2016 - May 2017). Consequently, the lower $\delta^{15} \mathrm{~N}$ in predators may reflect the discrepancy between the isotope composition of the rapidly changing resources and the primary and secondary consumers, especially at these urban and agricultural sites. Commonly assumed constant trophic enrichment factor between predators and their potential prey is not always found under the changing field conditions (Post, 2002; Vanderklift \& Ponsard, 2003).

The changes in land use can alter the composition and availability of dietary resources for consumers, since higher nutrient loads facilitate the growth of a different community assemblage (Allan, 2004; Dülger, Heidbüchel, Schumann, Mettler-Altmann, \& Hussner, 2017). Whereas high nutrient concentrations likely contributed to the increased population densities of passive filterers and reduced densities of shredders at our urban sites, large predaceous Plecoptera (that are sensitive to nutrient pollution) were found at our woodland sites only (Table S2). Closed canopy cover in woodland sites also led to a reduction in periphyton primary production and a scarcity of in-stream higher aquatic resources. The greater contribution of macrophytes to the diets of primary consumers at urban sites reflected their prevalence at those sites relative to agricultural and woodland sites. Macrophytes can 
412 reduce the water flow velocity and the total discharge, which agrees with the negative

413 relationship between discharge and nutrient levels found in our study and elsewhere (Baldy,

414 Trémolières, Andrieu, \& Belliard, 2007; Dodds \& Biggs, 2002; Fig. S1a and b). Subsequent

415 decomposition of macrophytes and their ability to trap fine particles and aquatic organisms

416 within their roots and stems (Jones, Collins, Naden, \& Sear, 2012; Sertić Perić, Miliša,

417 Kepčija, Primc-Habdija, \& Habdija, 2011) further enhances their contribution to the diet of

418 macroinvertebrates. By removing the epiphytic cover from macrophytes, macroinvertebrate

419 grazers might further promote their growth (Bronmark, 1985; Sand-Jensen \& Borum, 1984).

420 In agreement with recent findings (Rovira, Alcaraz, \& Trobajo, 2016), our work suggests that

421 intensive land use may increase the role of macrophytes in stream food webs.

The grouping of dietary items, into the higher and lower aquatic resources and use (Neres-Lima et al., 2017; Phillips, Newsome, \& Gregg 2005). We expected terrestrial resources to be more important at woodland sites as leaf litter dominates the nutrient input of many forested streams, and the canopy reduces light availability for growth of autochthonous primary producers (Neres-Lima et al., 2017; Rounick, Winterbourn, \& Lyon 1982). However, besides leaf litter, the terrestrial resources also included terrestrial plants (mainly grasses and riparian herbaceous plants), which largely contributed to the consumers' diet at urban and agricultural sites. The lack of leaf litter and the dominance of riparian grass (i.e. C4 plants) at the urban sites was further reflected in the absence of macroinvertebrate shredders, which mainly rely on processing the leaf litter-CPOM (Moog, 2002). Furthermore, considering their range in $\delta^{13} \mathrm{C}$ values ( -39.4 to $-11.4 \%$ ), primary consumers can switch their diet from riparian vegetation sources (ranging from $-27 \%$ to $-13 \%$ within the terrestrial $\mathrm{C} 3$ and $\mathrm{C} 4$ 435 plants, respectively) to aquatic macrophytes ( $\delta^{13} \mathrm{C}$ range: $-27 \%$ to $-20 \%$ ) and periphyton $436\left(\delta^{13} \mathrm{C}\right.$ range: $-35 \%$ to $-18 \%$ ) (Finlay \& Kendall, 2007). This suggests that the herbivorous 
and omnivorous macroinvertebrates can select autochthonous resources, even when terrestrial food resources are common, which agrees with invertebrate feeding patterns in Danish forest streams (Friberg \& Jacobsen, 1994).

Despite the difference in the dietary sources, macroinvertebrate consumers had similar overall isotopic variance across the three land use categories. This may indicate that a similar range of habitats is being exploited by consumers (Rader et al., 2017). However, the measure of isotopic variance may include some individuals that may have obtained their isotopic signature from a region with a contrasting land use to the sites where they were sampled. We must also consider that isotopic estimates of diet contributions can be influenced by nontrophic determinants (Gorokhova, 2017), that dietary estimation can lack reliability when applied to complex diet mixtures (Nielsen et al., 2018) and is highly sensitive to missing resources (Phillips et al., 2014). Still, the isotope approach offers a robust space- and timeintegrated overview of diet composition, which gives an insight beyond the limitations of morphological and molecular faecal and gut analyses.

We provide evidence for the strong influence of land use on $\delta^{15} \mathrm{~N}$ enrichment of predators, primary consumers and basal resources. Functional and isotopic composition of basal resources and prey across land use types were reflected at the level of primary consumers and predators, respectively. This indicates a bottom-up control of food webs surrounded by intensive agriculture and urban development. More fragile food webs evidenced by low trophic redundancy in urban zones with high nutrient loads may be less resistant to ongoing and accelerating global and local environmental change. These findings demonstrate how alterations to land use reshuffle the flow of biomass and energy through ecosystems. Human population growth and increasing impacts of urbanization and agricultural land use across all trophic levels need to be considered in our efforts to understand, conserve and restore the human-modified ecosystems. 


\section{Acknowledgements}

464 We thank the members of the Kratina Research Group, Victoria Kemp, associate editor and three anonymous reviewers for constructive comments on the manuscript. Jens Nielsen provided guidance on mixing models and commented on the manuscript. We also thank the members of the Department of Biology and Department of Chemistry, Faculty of Science, University of Zagreb for the logistical support during the research. Marta Mikulčić assisted with sample collection in the field. The study was financially supported by the Croatian Academy of Sciences and Arts to MSP. PK and GQR gratefully acknowledge funding from the Royal Society (grant NAF\R2\180791), GQR was also supported by BPE-FAPESP (grant 2016/01209-9) and CNPq-Brazil research grants. The authors declare no competing financial 473 interests.

\section{Author Contributions}

PK and MSP conceived the idea and designed the study; MSP and ELP collected the data;

477 GQR, PK and ELP performed the statistical analyses. ELP and PK drafted the manuscript with inputs from all authors. All authors contributed substantially to revisions and the final format of the manuscript.

\section{Data Accessibility}

Data will be archived in the public archive Dryad (http://datadryad.org). 


\section{References}

485

486

487

488

489

490

491

492

493

494

495

496

497

498

499

500

501

502

503

504

505

506

Allan, D. J. (2004). Landscapes and riverscapes: The influence of land use on stream ecosystems. Annual Review of Ecology, Evolution, and Systematics, 35, 257-284. doi:10.1146/annurev.ecolsys.35.120202

Alley, T. R. (1982). Competition theory, evolution, and the concept of an ecological niche. Acta Biotheoretica, 31(3), 165-179. doi:https://doi.org/10.1007/BF01857239

APHA. (1985). Standard Methods for the Examination of Water and Wastewater. American Public Health Association, Washington.

Baldy, V., Trémolières, M., Andrieu, M., \& Belliard, J. (2007). Changes in phosphorus content of two aquatic macrophytes according to water velocity, trophic status and time period in hardwater streams. Hydrobiologia, 575(1), 343-351. doi:10.1007/s10750-0060380-0

Baumgartner, S. D., \& Robinson, C. T. (2017). Changes in macroinvertebrate trophic structure along a land-use gradient within a lowland stream network. Aquatic Sciences, 79(2), 407-418. doi:10.1007/s00027-016-0506-z

Beaugrand, G., Mackas, D., \& Goberville, E. (2013). Applying the concept of the ecological niche and a macroecological approach to understand how climate influences zooplankton: Advantages, assumptions, limitations and requirements. Progress in Oceanography, 111, 75-90. doi:10.1016/j.pocean.2012.11.002

Bergfur, J., Johnson, R. K., Sandin, L., \& Goedkoop, W. (2009). Effects of nutrient enrichment on $\mathrm{C}$ and $\mathrm{N}$ stable isotope ratios of invertebrates, fish and their food resources in boreal streams. Hydrobiologia, 628(1), 67-79. doi:10.1007/s10750-0099746-4 
507

508

509

510

511

512

513

514

515

516

517

518

519

520

521

522

523

524

525

526

527

528

529

Brett, M. T. (2014). Resource polygon geometry predicts Bayesian stable isotope mixing model bias. Marine Ecology Progress Series, 514, 1-12. doi:10.3354/meps11017

Brett, M. T., Kainz, M. J., Taipale, S. J., \& Seshan, H. (2009). Phytoplankton, not allochthonous carbon, sustains herbivorous zooplankton production. Proceedings of the National Academy of Sciences of the United States of America, 106(50), 21197-21201. doi:10.1073/pnas.0904129106

Bronmark, C. (1985). Interactions between macrophytes, epiphytes and herbivores: an experimental approach. Oikos, 45(1), 26-30. doi:10.2307/3565218

Capuzzo, E., Lynam, C. P., Barry, J., Stephens, D., Forster, R. M., Greenwood, N., ... Engelhard, G. H. (2017). A decline in primary production in the North Sea over twentyfive years, associated with reductions in zooplankton abundance and fish stock recruitment. Global Change Biology, 24(1), 1-13. doi:10.1111/gcb.13916

Cardinale, B. J., Palmer, M. a, \& Collins, S. L. (2002). Species diversity enhances ecosystem functioning through interspecific facilitation. Nature, 415(6870), 426-9. doi: $10.1038 / 415426 a$

Carpenter, S. R., Cole, J. J., Kitchell, J. F., \& Pace, M. L. (1998). Impact of dissolved organic carbon, phosphorus, and grazing on phytoplankton biomass and production in experimental lakes. Limnology and Oceanography, 43(1), 73-80. doi:10.4319/1o.1998.43.1.0073

Caut, S., Angulo, E., \& Courchamp, F. (2009). Variation in discrimination factors ( $\Delta 15 \mathrm{~N}$ and $\Delta 13 \mathrm{C}$ ): the effect of diet isotopic values and applications for diet reconstruction. Journal of Applied Ecology, 46, 443-453. doi:10.1111/j.1365-2664.2009.01620.x

Chapin, I. S. F., Zavaleta, E. S., Eviner, V. T., Naylor, R. L., Vitousek, P. M., Reynolds, H. 
530

531

532

533

534

535

536

537

538

539

540

541

542

543

544

545

546

547

548

549

550

551

552

L., ... Díaz, S. (2000). Consequences of changing biodiversity. Nature, 405, 234-242. doi: $10.1038 / 35012241$

Chen, X., Mcgowan, S., Zeng, L., Xu, L., \& Yang, X. (2017). Changes in carbon and nitrogen cycling in a floodplain lake over recent decades linked to littoral expansion, declining riverine influx, and eutrophication. Hydrologiclal Processes, 31, 3110-3121. doi:10.1002/hyp.11254

Clergeau, P., Croci, S., Jokimäki, J., Kaisanlahti-Jokimäki, M. L., \& Dinetti, M. (2006). Avifauna homogenisation by urbanisation: Analysis at different European latitudes. Biological Conservation, 127(3), 336-344. doi:10.1016/j.biocon.2005.06.035

Cole, M. L., Valiela, I., Kroeger, K. D., Tomasky, G. L., Cebrian, J., Wigand, C., ... Carvalho da Silva, M. H. (2004). Assessment of a $\delta 15 N$ Isotopic Method to Indicate Anthropogenic Eutrophication in Aquatic Ecosystems. Journal of Environmental Quality, 33(1), 124-132. doi:10.2134/jeq2004.0124

Coors, A., \& De Meester, L. (2008). Synergistic, antagonistic and additive effects of multiple stressors: predation threat, parasitism and pesticide exposure in Daphnia magna. Journal of Applied Ecology, 45, 1820-1828. doi:10.1111/j.1365-2664.2007.0

Cucherousset, J., \& Villéger, S. (2015). Quantifying the multiple facets of isotopic diversity: New metrics for stable isotope ecology. Ecological Indicators, 56, 152-160. doi:10.1016/j.ecolind.2015.03.032

De Castro, D. M. P., De Carvalho, D. R., Pompeu, P. D. S., Moreira, M. Z., Nardoto, G. B., $\&$ Callisto, M. (2016). Land use influences niche size and the assimilation of resources by benthic macroinvertebrates in tropical headwater streams. PLOS ONE, 11(3), 1-19. doi:10.1371/journal.pone.0150527 
553 Deutsches Institut für Normung. (1986). German standard methods for the examination of water, waste water and sludge; sludge and sediments (group S); determination of the amenability to anaerobic digestion. Deutsches Institut Für Normung.

Dodds, W. K., \& Biggs, B. J. F. (2002). Water velocity attenuation by stream periphyton and macrophytes in relation to growth form and architecture. Journal of North American

Friberg, N., \& Jacobsen, D. (1994). Feeding plasticity of two detriviore-shredders.

Finlay, J. C., Khandwala, S., \& Power, M. E. (2002). Spatial scales of carbon flow in a river food web. Ecology, 83(7), 1845-1859. doi:10.1890/00129658(2002)083[1845:SSOCFI]2.0.CO;2 Freshwater Biology, 32, 133-142. doi:10.1111/j.1365-2427.1994.tb00873.x

Gorokhova, E. (2017). Individual growth as a non-dietary determinant of the isotopic niche metrics. Methods in Ecology and Evolution, 00, 1-9. doi:10.1111/ijlh.12426

Guignard, M. S., Leitch, A. R., Acquisti, C., Eizaguirre, C., Elser, J. J., Hessen, D. O., ... Leitch, I. J. (2017). Impacts of nitrogen and P phosphorus: from genomes to natural ecosystems and agriculture. Frontiers in Ecology and Evolution, 5(70), 1-9. 

doi:10.3389/fevo.2017.00070

577

Halvorson, H. M., Fuller, C. L., Entrekin, S. A., Scott, J. T., \& Evans-White, M. A. (2018). Detrital nutrient content and leaf species differentially affect growth and nutritional regulation of detritivores. Oikos, 127, 1471-1481. doi:10.1111/oik.05201

Harrington, R. R., Kennedy, B. P., Chamberlain, C. P., Blum, J. D., \& Folt, C. L. (1998). 15N enrichment in agricultural catchments: field patterns and applications to tracking Atlantic salmon (Salmo salar). Chemical Geology, 147(4), 281-294. doi:10.1016/S00092541(98)00018-7

Heaton, T. H. E. (1986). Isotopic studies of nitrogen pollution in the hydrosphere and atmosphere: A review. Isotope Geoscience, 59(1), 87-102. doi:10.1016/01689622(86)90059-X

Heilpern, S. A., Weeks, B. C., \& Naeem, S. (2018). Predicting ecosystem vulnerability to biodiversity loss from community composition. Ecology, 99(5), 1099-1107. doi:10.1002/ecy.2219

Jackson, A. L., Inger, R., Parnell, A. C., \& Bearhop, S. (2011). Comparing isotopic niche widths among and within communities: SIBER - Stable Isotope Bayesian Ellipses in R. Journal of Animal Ecology, 80, 595-602. doi:10.1111/j.1365-2656.2011.01806.x

Jones, J. I., Collins, A. L., Naden, P. S., \& Sear, D. A. (2012). The relationship between fine sediment and macrophytes in rivers. River Research and Applcication, 28, 1006-1018. doi:10.1002/rra

Junker, J. R., \& Cross, W. F. (2014). Seasonality in the trophic basis of a temperate stream invertebrate assemblage: Importance of temperature and food quality. Limnology and Oceanography, 59(2), 507-518. doi:10.4319/lo.2014.59.2.0507 
599 Karlsson, J., Bergström, A., Byström, P., Gudasz, C., Rodriguez, P., \& Hein, C. (2015). 600 Terrestrial organic matter input suppresses biomass production in lake ecosystems. 601 Ecology, 96(11), 2870-2876. doi:10.1890/15-0515.1

602

603

604

605

606

607

608

609

610

611

612

613

614

615

616

617

618

619

620

621

Kiffney, P. M., Buhle, E. R., Naman, S. M., Pess, G. R., \& Klett, R. S. (2014). Linking resource availability and habitat structure to stream organisms: an experimental and observational assessment. Ecosphere, 5(4), 1-27. doi:10.1890/ES13-00269.1

Kratina, P., \& Winder, M. (2015). Biotic invasions can alter nutritional composition of zooplankton communities. Oikos, 124(1), 1337-1345. doi:10.1111/oik.02240

Lau, D. C. P., Leung, K. M. Y., \& Dudgeon, D. (2009). Are autochthonous foods more important than allochthonous resources to benthic consumers in tropical headwater streams? Journal of the American Benthological Society, 28(2), 426-439. doi:10.1899/07-079.1

Layman, C. A., Arrington, D. A., Montaña, C. G., \& Post, D. M. (2007). Can stable isotope ratios provide for community-wide measures of trophic structure? Ecology, 88(1), 4248. doi:10.1890/0012-9658(2007)88[42:CSIRPF]2.0.CO;2

Layman, C. A., John, P., Peyer, C. M., \& Allgeier, J. E. (2007). Niche width collapse in a resilient top predator following ecosystem fragmentation. Ecology Letters, 10, 937-944. doi:10.1111/j.1461-0248.2007.01087.x

Lister, B. C., \& Garcia, A. (2018). Climate-driven declines in arthropod abundance restructure a rainforest food web. Proceedings of the National Academy of Sciences, 115(44), E10397-E10406. doi:10.1073/pnas.1722477115

Mason, N. W. H., Mouillot, D., Graham, N. A. J., \& Bellwood, D. R. (2013). A functional approach reveals community responses to disturbances. Trends in Ecology \& Evolution, 
622

623

624

625

626

627

628

629

630

631

632

633

634

635

636

637

638

639

640

641

642

643

644

28(3), 167-177. doi:10.1016/j.tree.2012.10.004

McConnaughey, T., \& McRoy, C. P. (1979). Food-web structure and the fractionation of carbon isotopes in the Bering Sea. Marine Biology, 53, 257-262. doi:10.1007/BF00952434

McCutchan Jr, J. H., Lewis Jr, W. M., Kendall, C., \& McGrath, C. C. (2003). Variation in trophic shift for stable isotope ratios of carbon, nitrogen, and sulfur. Oikos, 102, 378390. doi:10.1034/j.1600-0706.2003.12098.x

McKinney, M. L. (2006). Urbanization as a major cause of biotic homogenization. Biological Conservation, 127(3), 247-260. doi:10.1016/j.biocon.2005.09.005

Moog, O. (2002). Fauna Aquatica Austriaca. (M. O, Ed.) (2nd ed.). Federal Ministry of Agriculture, Forestry, Environment and Water Management, Vienna.

Neres-Lima, V., Machado-Silva, F., Baptista, D. F., Oliveira, R. B. S., Andrade, P. M., Oliveira, A. F., ... Moulton, T. P. (2017). Allochthonous and autochthonous carbon flows in food webs of tropical forest streams. Freshwater Biology, (62), 1012-1023. doi:10.1111/fwb.12921

Newsome, S. D., Rio, C. M. del, Bearhop, S., \& Phillips, D. L. (2007). A niche for isotopic ecology. Frontiers in Ecology and the Environment, 5(8), 429-436. doi:10.1890/060150.01

Nielsen, J. M., Clare, E. L., Hayden, B., Brett, M. T., \& Kratina, P. (2018). Diet tracing in ecology: method comparison and selection. Methods in Ecology and Evolution, 8(9), 1023-1168. doi:10.1111/ijlh.12426

Nusch, E. A. (1980). Comparison of different methods for chlorophyll and phaeopigment determination. Archives Für Hydrobiology, 14, 14-36. 
645 Ormerod, S. J., Dobson, M., Hildrew, A. G., \& Townsend, C. R. (2010). Multiple stressors in 646 freshwater ecosystems. Freshwater Biology, 55(Suppl. 1), 1-4. doi:10.1111/j.1365-

647 2427.2009.02395.x

648

649

650

651

652

653

654

655

656

657

658

659

660

661

662

663

664

665

666

667

Parnell, A. C., Phillips, D. L., Bearhop, S., Semmens, B. X., Ward, E. J., Moore, J. W., ... Inger, R. (2013). Bayesian stable isotope mixing models. Environmetrics, 24(6), 387399. doi:10.1002/env.2221

Pastor, A., Riera, J. L., Peipoch, M., Cañas, L., Ribot, M., Gacia, E., ... Sabater, F. (2014). Temporal variability of nitrogen stable isotopes in primary uptake compartments in four streams differing in human impacts. Environmental Science and Technology, 48(12), 6612-6619. doi:10.1021/es405493k

Perkins, M. J., Mcdonald, R. A., van Veen, F. J. F., Kelly, S. D., Rees, G., \& Bearhop, S. (2013). Important impacts of tissue selection and lipid extraction on ecological parameters derived from stable isotope ratios. Methods in Ecology and Evolution, 4(10), 944-953. doi:10.1111/2041-210X.12098

Phillips, D. L., Inger, R., Bearhop, S., Jackson, A. L., Moore, J. W., Parnell, A. C., ... Ward, E. J. (2014). Best practices for use of stable isotope mixing models in food-web studies. Canadian Journal of Zoology, 92, 823-835. doi:10.1139/cjz-2014-0127

Phillips, D. L., Newsome, S. D., \& Gregg, J. W. (2005). Combining sources in stable isotope mixing models: Alternative methods. Oecologia, 144(4), 520-527. doi:10.1007/s00442004-1816-8

Pinheiro, J., \& Bates, D. (2000). Mixed-effects models in S and S-PLUS. (1st ed.). SpringerVerlag New York. doi:10.1007/b98882

Post, D. M. (2002). Using Stable Isotopes to Estimate Trophic Position: Models , Methods, 
and Assumptions. Ecology, 83(3), 703-718. doi:10.1890/00129658(2002)083[0703:USITET]2.0.CO;2

Post, D. M., Layman, C. A., Arrington, D. A., Takimoto, G., Quattrochi, J., \& Montaña, C. G. (2007). Getting to the fat of the matter: Models, methods and assumptions for dealing with lipids in stable isotope analyses. Oecologia, 152(1), 179-189. doi:10.1007/s00442006-0630-x

R Development Core Team. (2015). R: A Language and Environment for Statistical Computing. R Foundation for Statistical Computing. Retrieved from https://www.rproject.org

Rader, J. A., Newsome, S. D., Sabat, P., Chesser, R. T., Dillon, M. E., \& Martínez del Rio, C. (2017). Isotopic niches support the resource breadth hypothesis. Journal of Animal Ecology, 86(2), 405-413. doi:10.1111/1365-2656.12629

Recalde, F. C., Postali, T. C., \& Romero, G. Q. (2016). Unravelling the role of allochthonous aquatic resources to food web structure in a tropical riparian forest. Journal of Animal Ecology, 85(2), 525-536. doi:10.1111/1365-2656.12475

Risk, M. J., Lapointe, B. E., Sherwood, O. A., \& Bedford, B. J. (2009). The use of d15N in assessing sewage stress on coral reefs. Marine Pollution Bulletin, 58(6), 793-802. doi:10.1016/j.marpolbul.2009.02.008

Rounick, J. S., Winterbourn, M. J., \& Lyon, G. L. (1982). Differential utilization of allochthonous and autochthonous inputs by aquatic invertebrates in some New Zealand streams: A stable carbon isotope study. Oikos, 39(2), 191-198. doi:10.2307/3544485

Rovira, A., Alcaraz, C., \& Trobajo, R. (2016). Effects of plant architecture and water velocity on sediment retention by submerged macrophytes. Freshwater Biology, 61, 758-768. 

doi:10.1111/fwb.12746

692

Saito, L., Rosen, M. R., Chandra, S., Fritsen, C. H., Arufe, J. A., \& Redd, C. (2008). Using semi-permeable membrane devices and stable nitrogen isotopes to detect anthropogenic influences on the Truckee River, USA. Environmental Engineering Science, 25(4), 585600. doi:10.1089/ees.2007.0090

Sala, O. E., Iii, F. S. C., Armesto, J. J., Berlow, E., Bloomfield, J., Dirzo, R., ... Walker, M. (2000). Global Biodiversity Scenarios for the Year 2100. Science, 287(5459), 17701774. doi:10.1126/science.287.5459.1770

Sand-Jensen, K., \& Borum, J. (1984). Epiphyte shading and its effect on photosynthesis and diel metabolism of Lobelia dortmanna L. during the spring bloom in a danish lake. Aquatic Botany, 20(1-2), 109-119. doi:10.1016/0304-3770(84)90031-7

Sertić Perć, M., Miliša, M., Kepčija, R. M., Primc-Habdija, B., \& Habdija, I. (2011). Seasonal and fine-scale spatial drift patterns in a tufadepositing barrage hydrosystem. Fundamental and Applied Limnology / Archiv Für Hydrobiologie, 178(2), 131-145. doi:10.1127/1863-9135/2011/0178-0131

Shurin, J. B., Clasen, J. L., Greig, H. S., Kratina, P., \& Thompson, P. L. (2012). Warming shifts top-down and bottom-up control of pond food web structure and function. Philosophical Transactions of the Royal Society of London. Series B, Biological Sciences, 367, 3008-3017. doi:10.1098/rstb.2012.0243

Stock, B. C., \& Semmens, B. X. (2013). MixSIAR GUI User Manual. Version 3.1. https://github.com/brianstock/MixSIAR., 56159. doi:10.5281/zenodo.56159.

Strayer, D. L., \& Dudgeon, D. (2010). Freshwater biodiversity conservation : recent progress and future challenges Freshwater biodiversity conservation : recent progress and future 
challenges. Journal of the North American Benthological Society, 29(1), 344-358. doi:10.1899/08-171.1

Thorp, J. H., \& Delong, M. D. (2002). Dominance of autochthonous autotrophic carbon food webs of heterotrophic rivers. Oikos, 96(3), 543-550. doi.org/10.1034/j.16000706.2002.960315.x

Vanderklift, M. A., \& Ponsard, S. (2003). Sources of variation in consumer-diet $\delta 15 \mathrm{~N}$ enrichment: A meta-analysis. Oecologia, 136(2), 169-182. doi:10.1007/s00442-003$1270-\mathrm{z}$

Vinebrooke, R. D., Cottingham, K. L., Norberg, J., Scheffer, M., Dodson, S. I., Maberly, S. C., \& Sommer, U. (2004). Impacts of multiple stressors on biodiversity and ecosystem functioning: the role of species co-tolerance. Oikos, 104(3), 451-457. doi:10.1111/j.0030-1299.2004.13255.x

Vitousek, P. M., Mooney, H. A., Lubchenco, J., \& Melillo, J. M. (1997). Human Domination of Earth's Ecosystems. Science, 277(5325), 494-499. doi:10.1126/science.277.5325.494

Wallace, J. B., \& Webster, J. R. (1996). The role of macroinvertebrates in stream ecosystem function. Annual Review of Entomology, 41(5322), 115-39. doi:10.1146/annurev.en.41.010196.000555

Walsh, C. J., Roy, A. H., Feminella, J. W., Cottingham, P. D., Groffman, P. M., \& Ii, R. P. M. (2005). The urban stream syndrome: current knowledge and the search for a cure. The University of Chicago Press Journals, 24(3), 706-723. doi:10.1899/04-028.1

Ward, C. L., \& Mccann, K. S. (2017). A mechanistic theory for aquatic food chain length. Nature Communications, 8(2028). doi:10.1038/s41467-017-02157-0

Zah, R., Burgherr, P., Bernasconi, S. M., \& Uehlinger, U. (2001). Stable isotope analysis of 
741 Figure 1. Locations of the fifteen study sites (red crosses) across the region of Zagreb,

742 Croatia. The dark grey lines indicate the stream network in Zagreb, flowing from the northern

743 area of Medvednica Nature Park through the human-modified areas and into the River Sava

744 (thick black line). Text boxes linked to the sites contain information on the land-use category

745 (W - woodland, A - agricultural, $\mathrm{U}-$ urban), altitude (m a.s.1.) and the mean $\delta^{15} \mathrm{~N}$ values of macroinvertebrates at each site. The coloration of each box corresponds to its mean $\delta^{15} \mathrm{~N}$ value as indicated by the colour-key.

Figure 2. (a) Proportional contributions (mean $\pm \mathrm{SE}$ ) of lower aquatic resources (LAR), higher aquatic resources (HAR) and terrestrial resources to the diets of primary consumers at urban, woodland and agricultural sites, as calculated by the SI mixing model. (b) Proportional contributions (mean $\pm \mathrm{SE}$ ) of the detritivores, grazers, shredders, passive filterers, and active filterers to the diets of macroinvertebrate predators in urban, woodland and agricultural sites.

Figure 3. The isotopic variance illustrated as a size of ellipses (SEAc, $\%^{2}$ ) for (a) basal represent urban sites, black ellipses and symbols represent agricultural sites, and green ellipses represent woodland sites. The ellipses were calculated only for the sites that included at least five samples from the focal trophic group. Each data point represents one individual or an accumulation of individuals in one sample where a single specimen did not contain enough dry weight. 
763 Figure 4. Nitrogen stable isotope ratios $\left(\delta^{15} \mathrm{~N}, \%\right.$ ) of (a) basal resources, (b) potential prey 764 (primary consumers), and (c) predators across the three land use categories. The box plots 765 illustrate the median (inner line), the interquartile range of the data (box), and the tails of the 766 distribution (bars $=1.5 \mathrm{x}$ interquartile range). Capital letters above the box plots denote 767 treatments (land use categories) not significantly different from each other.

769 Figure 5. Relationship between the physico-chemical characteristics, represented by the 770 Principal Component 1 axis (PC1; Fig. S1a \& b) and (a) trophic redundancy (MNND), (b) standard deviation of niche measures (SDNND), (c) mean $\delta^{15} \mathrm{~N}$, (d) $\delta^{15} \mathrm{~N}$ range at each site.

772 The black circles show food-web metrics calculated at each site, the blue line represents a significant fit of the linear mixed effects model to the data, and the shaded area is the $95 \%$ confidence interval. There was no significant relationship between the PC1 and the $\delta^{15} \mathrm{~N}$ range (see Results). PC1 explained 51.1\% of the variation in the physico-chemical characteristics at each site, and the concentrations of nitrites, nitrates, orthophosphates, conductivity and total water hardness were the strongest positive contributors to the PC1 axis. 


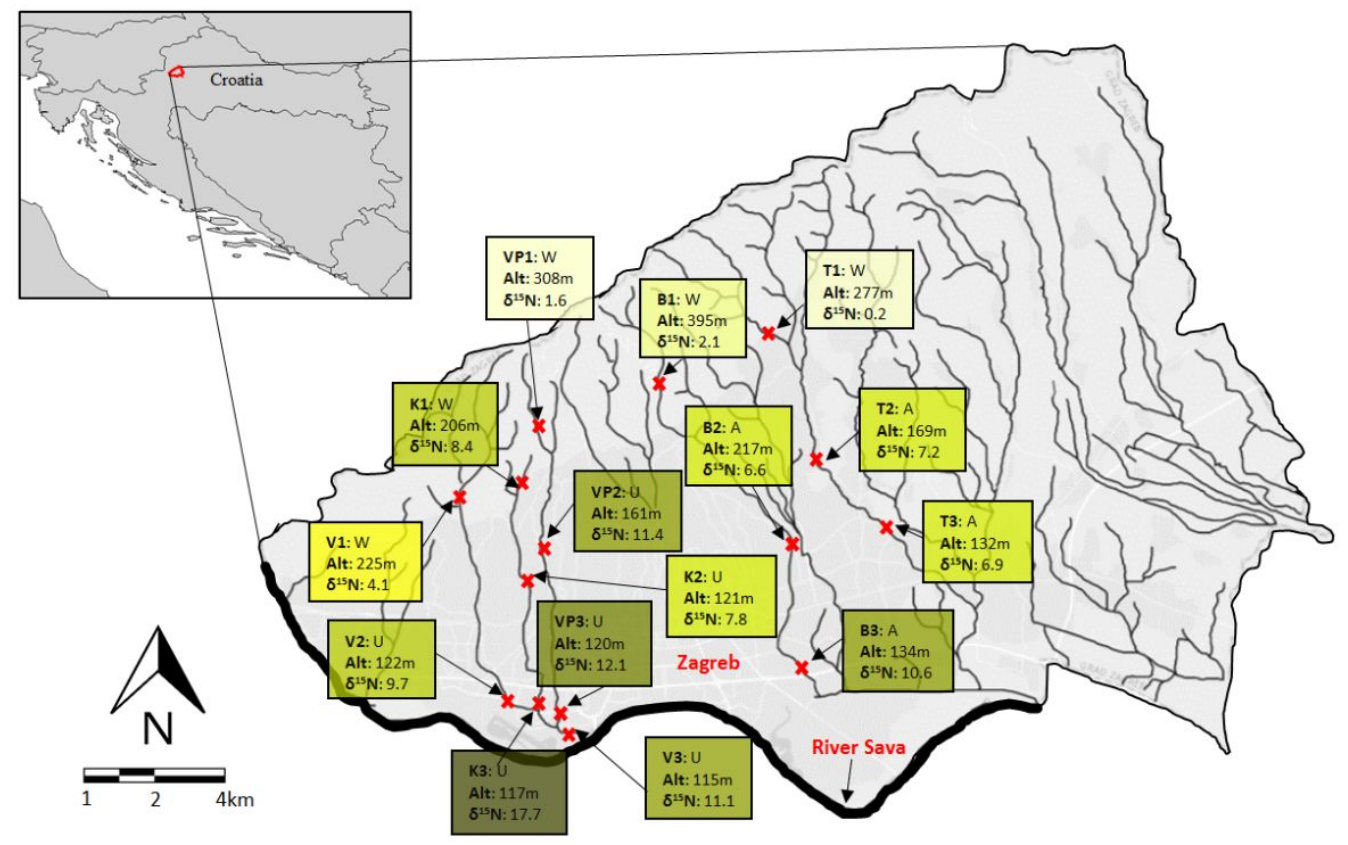

\section{0-2}

2-4

4-6

$6-8$

$8-10$

$10-12$

Figure 1 


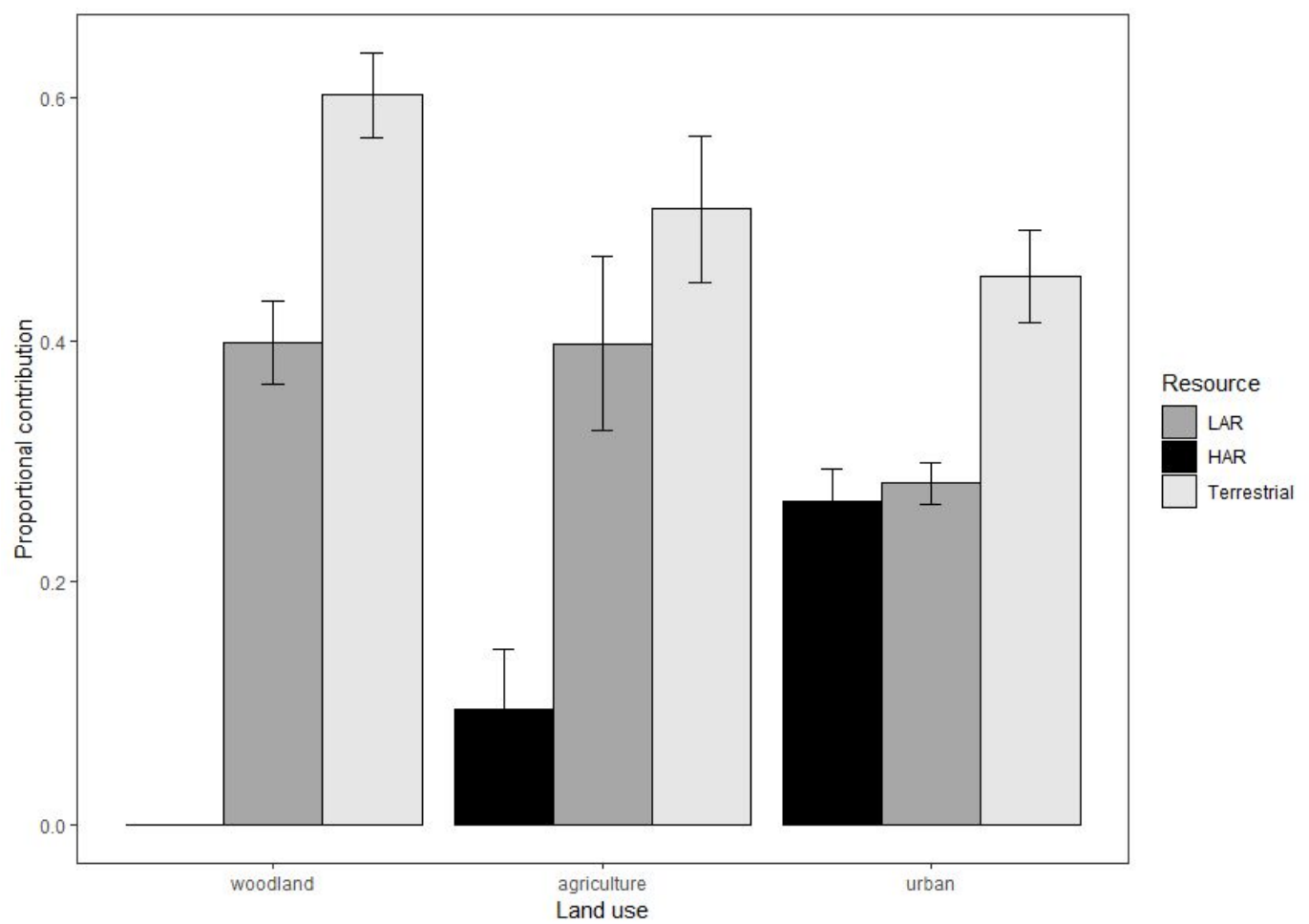

(b)

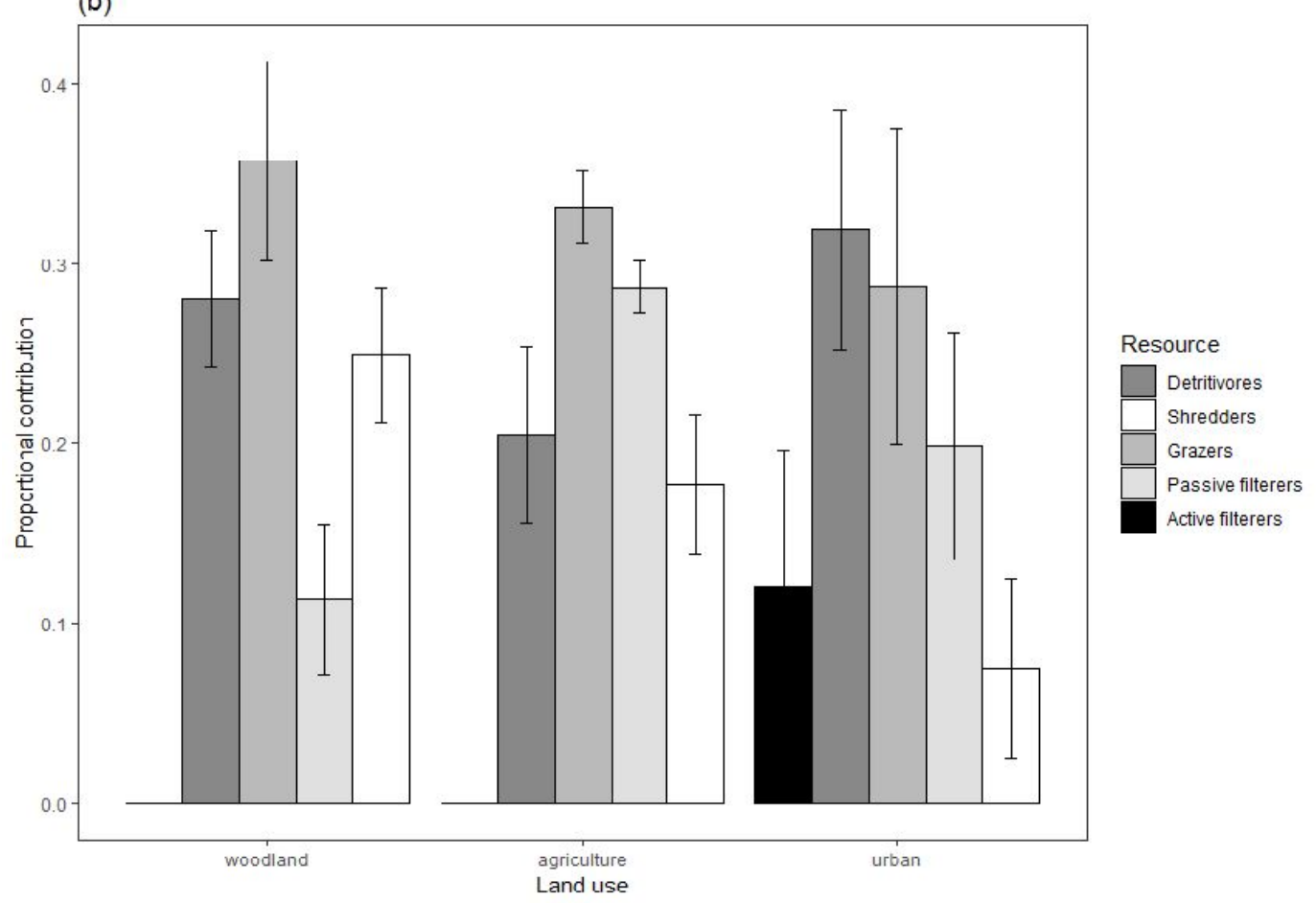

Figure 2 
(a)

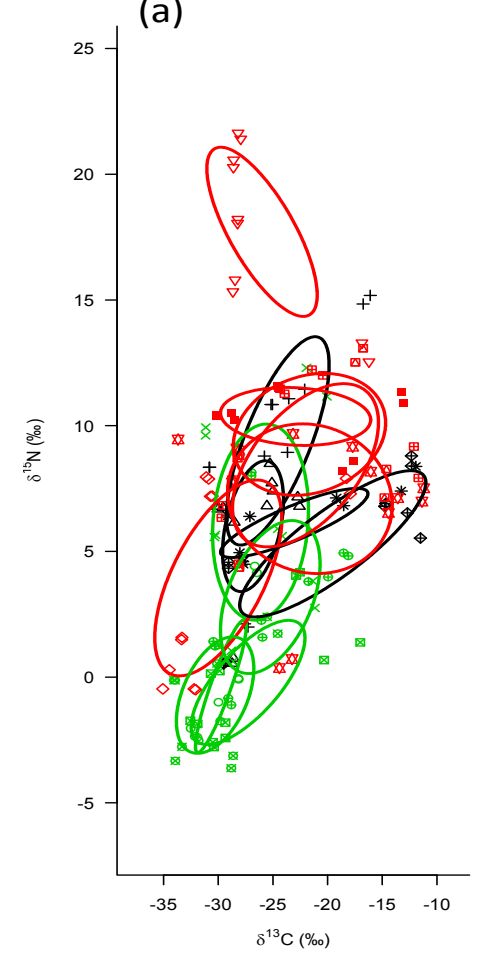

(b)

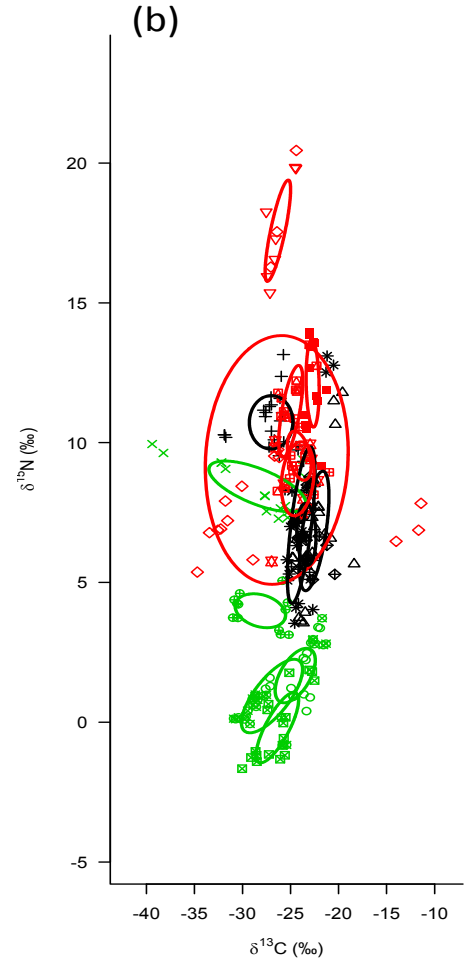

(c)

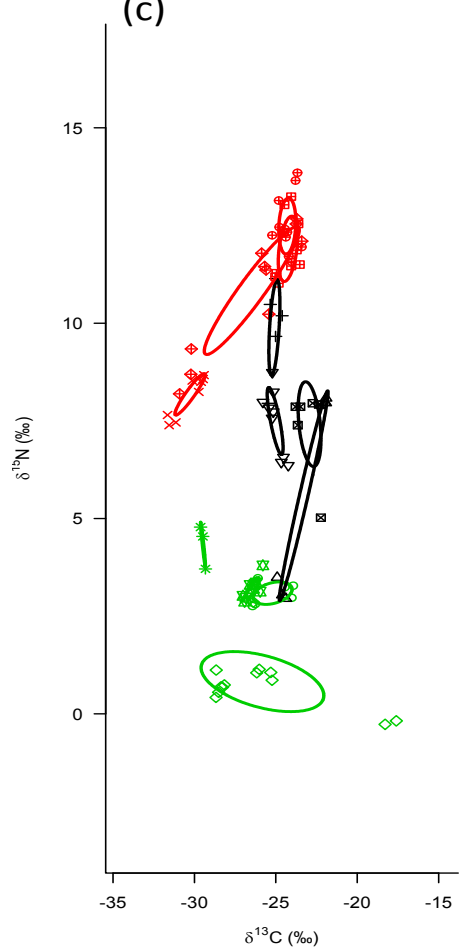

787 Figure 3 


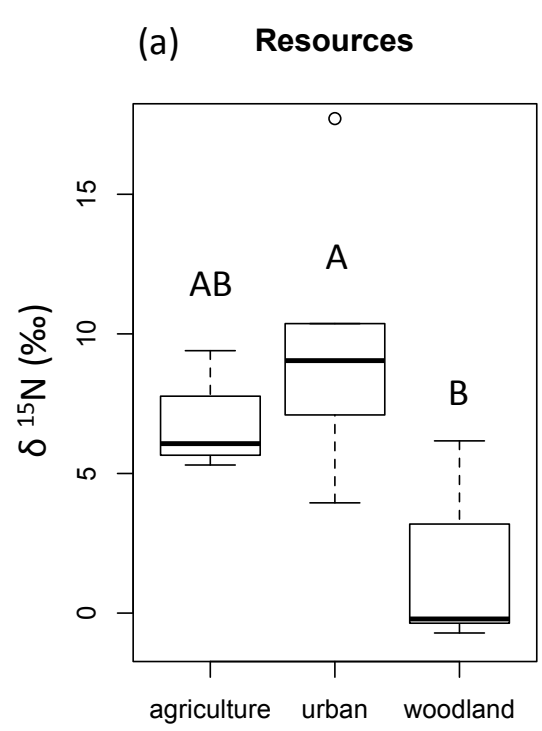

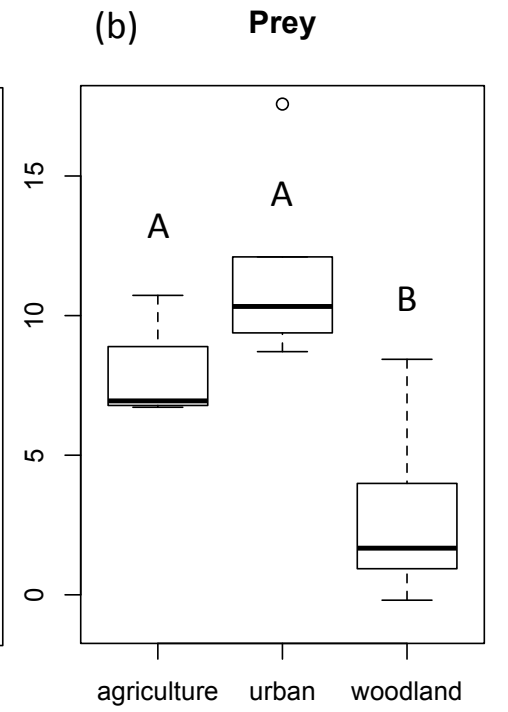

(b)

Land use (c) Predators

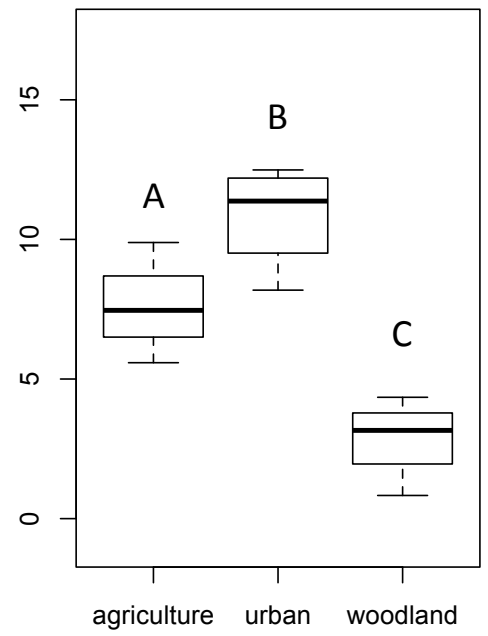

Figure 4 
(a)

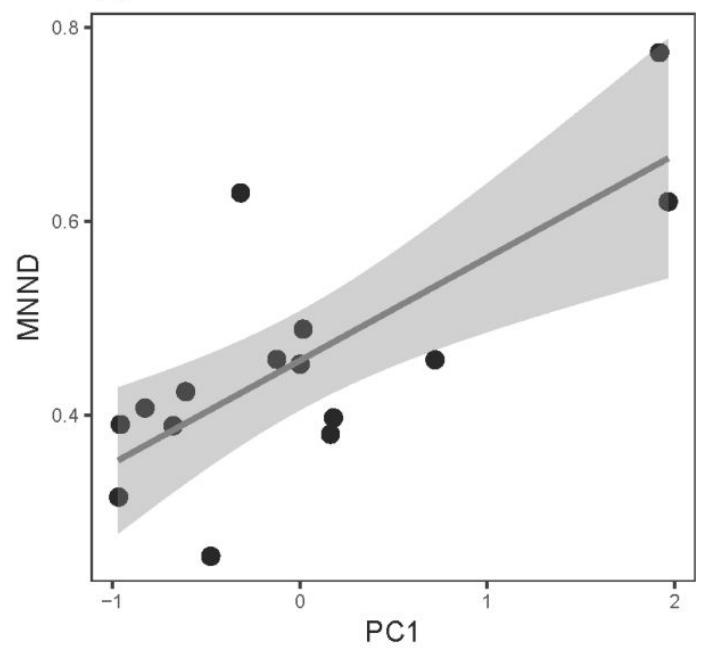

(c)

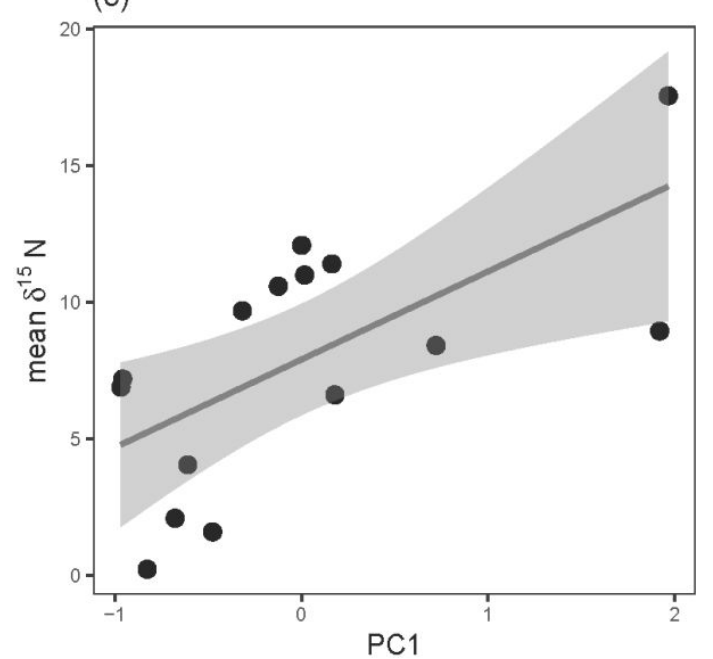

(b)

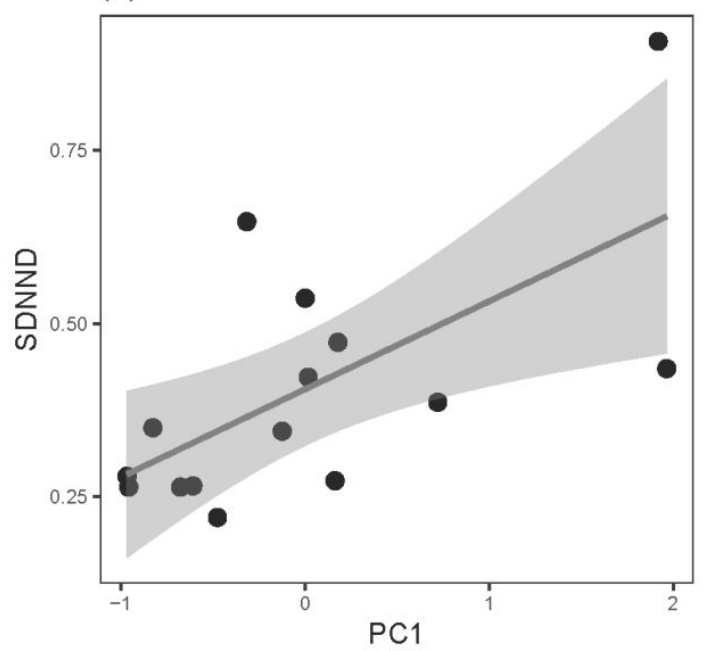

(d)

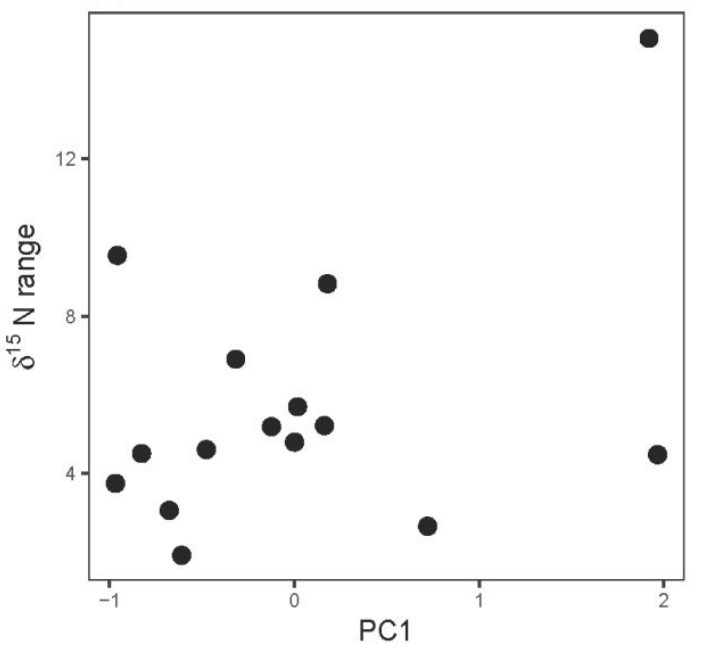

791

792

Figure 5 
Land use alters trophic redundancy and resource flow through stream food webs

\section{Supplementary Information}

Elliott L. Price ${ }^{1, *}$, Mirela Sertić Perić ${ }^{2}$, Gustavo Q. Romero ${ }^{3}$ \& Pavel Kratina ${ }^{1, *}$

${ }^{1}$ School of Biological and Chemical Sciences, Queen Mary University of London, Mile End Road, London, E1 4NS, United Kingdom

${ }^{2}$ University of Zagreb, Faculty of Science, Department of Biology, Rooseveltov trg 6, Zagreb, Croatia

${ }^{3}$ Departamento de Biologia Animal, Universidade Estadual de Campinas (UNICAMP), Campinas, Brazil

Current address: Department of Earth, Ocean and Ecological Sciences, University of Liverpool, Liverpool, L69 3BX, United Kingdom

*Corresponding Authors: elliott.price@liverpool.ac.uk,p.kratina@qmul.ac.uk 


\section{SUPPLEMENTARY FIGURES}

a)

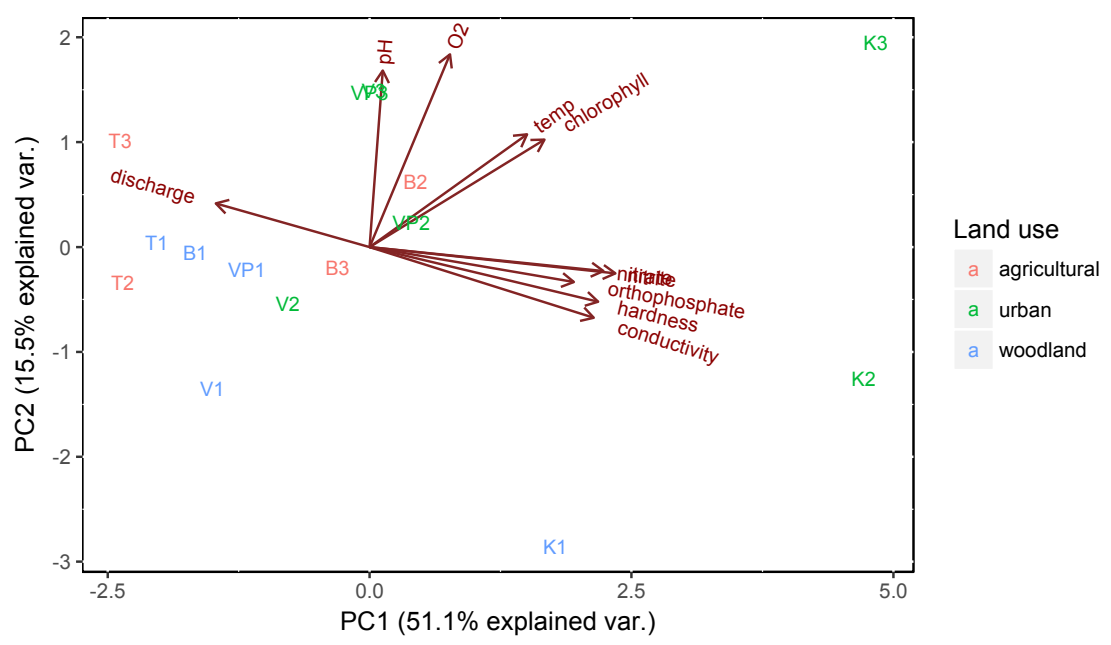

b)

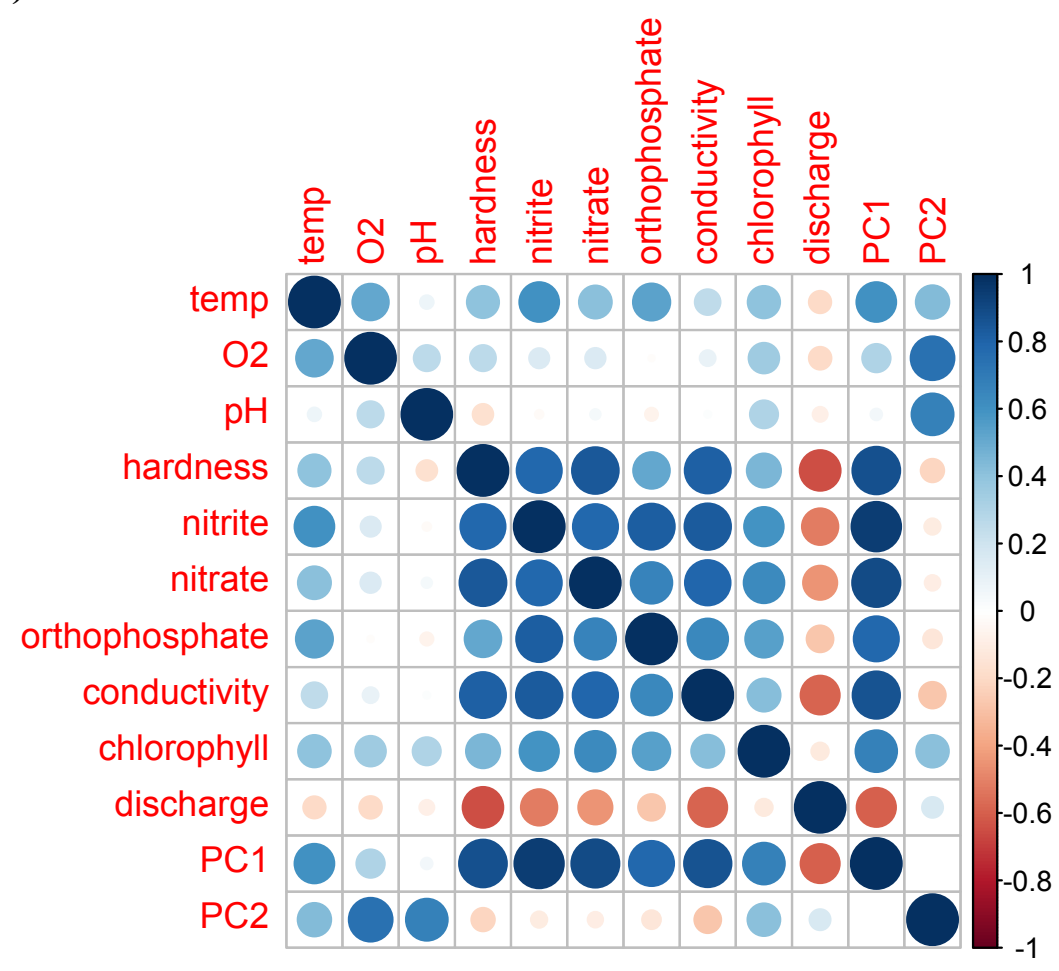

Figure S1. (a) The relationship between explanatory variables and the PC1 and PC2 axis for physico-chemical parameters. Explained variation (\%) refers to how much of the total variation in physico-chemical characteristics can be described by each axis. The greater the length of the arrow, the greater the contribution of that variable to PC1 and PC2. Coloured points represent the relationship of each site with $\mathrm{PC} 1$ and $\mathrm{PC} 2$. O2 - oxygen concentration $\left(\mathrm{mg} \mathrm{L}^{-1}\right)$; temp - water temperature $\left({ }^{\circ} \mathrm{C}\right)$; chlorophyll - chlorophyll- $a\left(\mathrm{Chl} a, \mu \mathrm{g} \mathrm{cm}^{-2}\right)$ concentration in periphyton samples. (b) Correlations matrix among explanatory variables and the PC1 and PC2 axis for physico-chemical parameters with circle size and colour intensity indicating the strength of the correlations. 
(a)

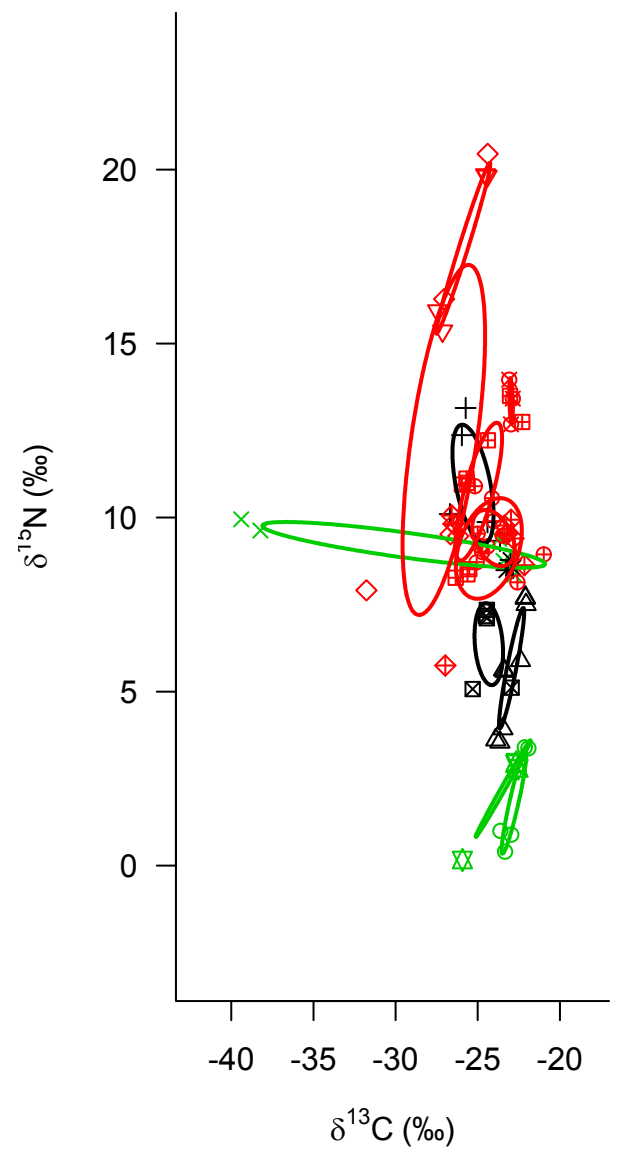

(b)

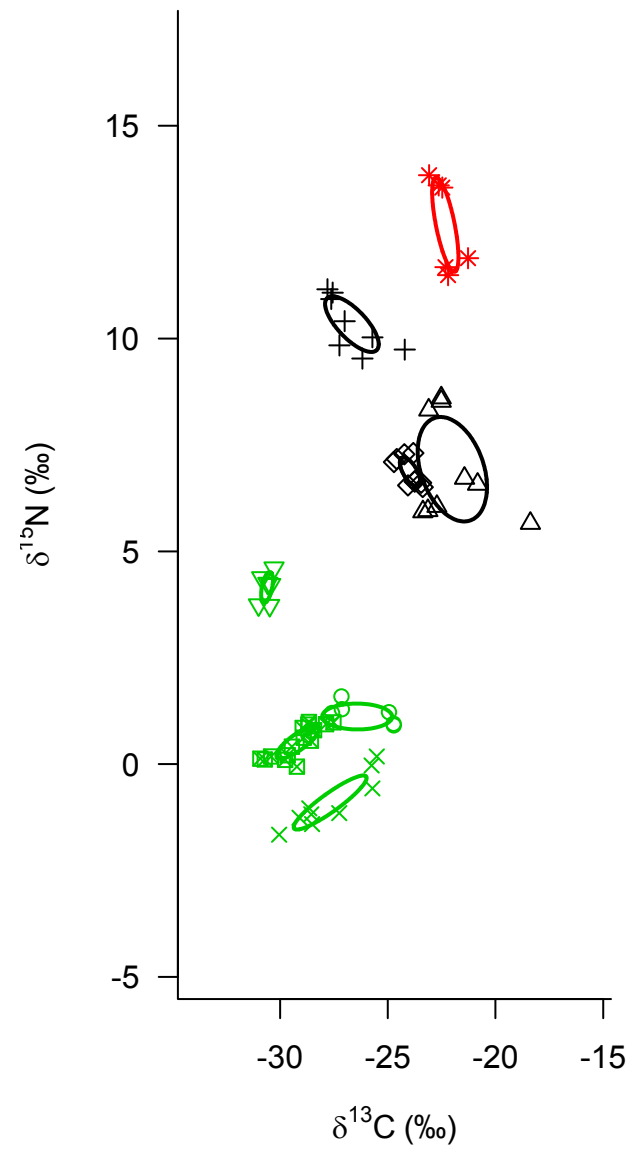

Figure S2. The isotopic variance illustrated as a size of ellipses (SEAc, $\%{ }^{2}$ ) for (a) detritivores and (b) grazers at each site. Red ellipses and symbols represent urban sites, black ellipses and symbols represent agricultural sites, and green ellipses represent woodland sites. The ellipses were calculated only for the sites that included at least five samples from the focal feeding group. 


\section{SUPPLEMENTARY TABLES}

Table S1. Physical and chemical characterization of the sampling sites under the three different land uses; Woodland (W), Agricultural (A) and Urban (U).

\begin{tabular}{|c|c|c|c|c|c|c|c|c|c|c|c|c|c|}
\hline \multirow[b]{2}{*}{ Stream } & \multirow[b]{2}{*}{ Site } & \multirow[b]{2}{*}{$\begin{array}{c}\text { Land } \\
\text { use }\end{array}$} & \multirow{2}{*}{$\frac{\text { Temperature }}{\left({ }^{\circ} \mathrm{C}\right)}$} & \multirow{2}{*}{$\begin{array}{c}\mathrm{O}_{2} \\
\left(\mathrm{mg} \mathrm{L}^{-1}\right)\end{array}$} & \multirow[t]{2}{*}{ pH } & \multirow{2}{*}{\multicolumn{2}{|c|}{$\begin{array}{cc}\text { COD } & \text { TWH } \\
\left(\mathrm{mg} \mathrm{O}_{2} \mathrm{~L}^{-1}\right)\left(\mathrm{mg} \mathrm{CaCO}_{3} \mathrm{~L}^{-1}\right) \\
\end{array}$}} & \multirow{2}{*}{$\begin{array}{c}\text { Nitrite } \\
\left(\mathrm{mg} \mathrm{L}^{-1}\right)\end{array}$} & \multirow{2}{*}{$\begin{array}{l}\text { Nitrate } \\
\left(\mathrm{mg} \mathrm{L}^{-1}\right)\end{array}$} & \multirow{2}{*}{$\begin{array}{c}\text { Orthophosphate } \\
\left(\mathrm{mg} \mathrm{L}^{-1}\right) \\
\end{array}$} & \multirow{2}{*}{$\begin{array}{c}\text { Conductivity } \\
\left(\mu \mathrm{S} \mathrm{cm}^{-1}\right) \\
\end{array}$} & \multirow{2}{*}{$\begin{array}{c}\text { Chlorophyll } a \\
\left(\mu \mathrm{g} \mathrm{cm}^{-2}\right) \\
\end{array}$} & \multirow{2}{*}{$\begin{array}{r}\text { Discharge } \\
\left(\mathrm{m}^{3} \mathrm{~s}^{-1}\right)\end{array}$} \\
\hline & & & & & & & & & & & & & \\
\hline \multirow[t]{3}{*}{ Vrapčak } & $\mathrm{V} 1$ & $\mathrm{~W}$ & 11.7 & 10.2 & 7.21 & 4.64 & 215.4 & 0.107 & 2.629 & 0.057 & 365 & 0.929 & 3.1 \\
\hline & $\mathrm{V} 2$ & $\mathrm{U}$ & 20.8 & 10.6 & 7.43 & 4.01 & 225.2 & 0.114 & 3.611 & 0.064 & 331 & 0.499 & 3.0 \\
\hline & $\mathrm{V} 3$ & $\mathrm{U}$ & 22.9 & 13.6 & 8.32 & 4.52 & 235.9 & 0.121 & 4.070 & 0.082 & 287 & 1.026 & 1.7 \\
\hline \multirow[t]{3}{*}{ Kustošak } & $\mathrm{K} 1$ & $\mathrm{~W}$ & 12.9 & 9.7 & 7.31 & 2.00 & 283.9 & 0.249 & 5.305 & 0.169 & 674 & 0.000 & 0.5 \\
\hline & $\mathrm{K} 2$ & $\mathrm{U}$ & 24.6 & 8.2 & 8.05 & 6.99 & 298.2 & 0.458 & 6.629 & 0.267 & 660 & 3.167 & 0.6 \\
\hline & $\mathrm{K} 3$ & $\mathrm{U}$ & 26.1 & 15.9 & 8.35 & 5.42 & 287.5 & 0.392 & 6.152 & 0.229 & 636 & 4.114 & 0.8 \\
\hline \multirow[t]{3}{*}{ Veliki potok } & K VP1 & W & 12.6 & 9.5 & 8.68 & 2.79 & 188.7 & 0.141 & 3.552 & 0.038 & 409 & 0.453 & 1.3 \\
\hline & VP2 & $\mathrm{U}$ & 16.7 & 9.7 & 8.85 & 3.85 & 197.6 & 0.147 & 4.394 & 0.192 & 476 & 1.391 & 2.4 \\
\hline & VP3 & $\mathrm{U}$ & 19.0 & 13.3 & 8.84 & 3.22 & 215.4 & 0.154 & 2.917 & 0.030 & 507 & 1.098 & 0.7 \\
\hline \multirow[t]{3}{*}{ Bliznec } & $\mathrm{B} 1$ & $\mathrm{~W}$ & 10.4 & 10.2 & 8.51 & 7.23 & 211.8 & 0.097 & 1.820 & 0.050 & 367 & 1.010 & 2.0 \\
\hline & B2 & A & 12.2 & 10.7 & 8.45 & 3.65 & 222.5 & 0.130 & 5.405 & 0.102 & 445 & 3.897 & 4.2 \\
\hline & B3 & A & 13.4 & 10.3 & 8.33 & 4.32 & 233.2 & 0.143 & 4.941 & 0.060 & 476 & 1.267 & 4.8 \\
\hline \multirow[t]{3}{*}{ Trnava } & $\mathrm{T} 1$ & $\mathrm{~W}$ & 14.1 & 9.7 & 8.10 & 2.04 & 145.1 & 0.102 & 2.082 & 0.112 & 261 & 1.281 & 3.1 \\
\hline & $\mathrm{T} 2$ & A & 16.3 & 9.7 & 7.87 & 1.93 & 147.7 & 0.093 & 1.776 & 0.108 & 332 & 0.000 & 5.0 \\
\hline & $\mathrm{T} 3$ & $\mathrm{~A}$ & 18.9 & 10.6 & 8.17 & 2.12 & 151.3 & 0.105 & 2.023 & 0.097 & 278 & 1.184 & 8.7 \\
\hline
\end{tabular}


Table S2. Taxonomic information and functional feeding groups (FFG) of stream macroinvertebrates found at each site and the respective land use. SHR - shredders, GRA grazers, DET - detritivores, AFIL - active filterers, PFIL - passive filterers, PRE - predators. Land use: W - woodland, A - agricultural, U - urban. For the site codes and locations refer to Fig. 1 and Materials and Methods.

\begin{tabular}{|c|c|c|c|c|}
\hline \multirow[b]{2}{*}{ CLASS/ORDER/Family } & \multirow[b]{2}{*}{ Subfamily/Genus/Species } & \multirow[b]{2}{*}{ FFG } & \multicolumn{2}{|l|}{ Presence } \\
\hline & & & Site & Land use \\
\hline \multicolumn{5}{|l|}{ PLATYHELMINTHES } \\
\hline Tricladida & Polycelis felina & PRE & $\mathrm{B} 2, \mathrm{~T} 3, \mathrm{~V} 1, \mathrm{VP} 1$ & $\mathrm{~W}, \mathrm{~A}$ \\
\hline \multicolumn{5}{|l|}{ GASTROPODA } \\
\hline \multirow[t]{2}{*}{ Lymnaeidae } & Pseudosuccinea columella & GRA & $\mathrm{B} 3, \mathrm{~T} 2$ & A \\
\hline & Stagnicola sp. & GRA & $\mathrm{VP} 3, \mathrm{~K} 3, \mathrm{~V} 2$ & $\mathrm{U}$ \\
\hline Physidae & Physa sp. & GRA & K2 & $\mathrm{U}$ \\
\hline \multicolumn{5}{|l|}{ BIVALVIA } \\
\hline Sphaeriidae & Pisidium sp. & AFIL & $\mathrm{K} 2$ & $\mathrm{U}$ \\
\hline \multicolumn{5}{|l|}{ OLIGOCHAETA } \\
\hline Lumbricidae & Eiseniella tetraedra & DET & $\mathrm{B} 2, \mathrm{~K} 2, \mathrm{~T} 2, \mathrm{VP} 2$ & $\mathrm{~A}, \mathrm{U}$ \\
\hline HIRUDINOMORPHA & Hirudinomorpha gen. sp. & PRE & B2 & A \\
\hline \multicolumn{5}{|l|}{ AMPHIPODA } \\
\hline Gammaridae & Gammarus fossarum & SHR & $\mathrm{B} 1, \mathrm{~B} 2, \mathrm{~K} 1, \mathrm{~T} 1, \mathrm{~T} 2, \mathrm{~T} 3, \mathrm{~V} 1, \mathrm{VP} 1$ & $\mathrm{~W}, \mathrm{~A}$ \\
\hline \multicolumn{5}{|l|}{ ISOPODA } \\
\hline Asellidae & Asellus aquaticus & DET & $\mathrm{B} 3, \mathrm{~K} 3, \mathrm{~V} 2, \mathrm{~V} 3$ & $\mathrm{~A}, \mathrm{U}$ \\
\hline \multicolumn{5}{|l|}{ COLEOPTERA } \\
\hline Elmidae & Elmidae gen. sp. & GRA & $\mathrm{T} 1$ & W \\
\hline \multicolumn{5}{|l|}{ DIPTERA } \\
\hline \multirow[t]{2}{*}{ Athericidae } & Atherix sp. & PRE & T1 & $\mathrm{W}$ \\
\hline & Ibisia marginata & PRE & T1, VP1 & $\mathrm{W}$ \\
\hline Ceratopogonidae & Ceratopogonidae gen. sp. & PRE & B3 & A \\
\hline \multirow[t]{5}{*}{ Chironomidae } & Chironomini gen. sp. & DET & $\mathrm{K} 3$, V3 & $\mathrm{U}$ \\
\hline & Chironomus sp. & DET & $\mathrm{B} 2, \mathrm{~B} 3, \mathrm{~V} 3, \mathrm{VP} 2, \mathrm{VP} 3, \mathrm{~K} 2, \mathrm{~T} 2, \mathrm{~T} 3, \mathrm{~V} 2$ & $\mathrm{~A}, \mathrm{U}$ \\
\hline & Orthocladiinae gen. sp. & GRA/DET & $\mathrm{B} 2, \mathrm{~B} 3, \mathrm{~K} 3, \mathrm{~V} 3$ & $\mathrm{~A}, \mathrm{U}$ \\
\hline & Tanypodinae gen. sp. & PRE & $\mathrm{K} 2, \mathrm{~T} 2, \mathrm{~T} 3, \mathrm{~V} 2, \mathrm{VP} 2$ & $\mathrm{~A}, \mathrm{U}$ \\
\hline & Tanytarsni gen. sp. & DET & VP3 & $\mathrm{U}$ \\
\hline \multirow[t]{2}{*}{ Limoniidae } & Limoniidae gen. sp. & PRE & $\mathrm{K} 1, \mathrm{~K} 2$ & $\mathrm{~W}, \mathrm{U}$ \\
\hline & Limnophila sp. & PRE & B1 & $\mathrm{W}$ \\
\hline Pediciidae & Dicranota sp. & PRE & $\mathrm{T} 1$ & $\mathrm{~W}$ \\
\hline Simuliidae & Prosimulium sp. & PFIL & $\mathrm{T} 2, \mathrm{~T} 3$ & A \\
\hline & Simulium sp. & PFIL & $\mathrm{B} 2, \mathrm{~B} 3, \mathrm{~K} 2, \mathrm{~T} 1, \mathrm{~T} 2, \mathrm{~V} 1, \mathrm{~V} 2$ & $\mathrm{~W}, \mathrm{~A}, \mathrm{U}$ \\
\hline Tipulidae & Tipulidae gen. sp. & SHR & $\mathrm{T} 2, \mathrm{~T} 3, \mathrm{VP} 3$ & $\mathrm{~A}, \mathrm{U}$ \\
\hline EPHEMEROPTERA & & & & \\
\hline Baetidae & Baetis sp. & GRA/DET & B1, B3, VP1, VP2, T1, V1 & $\mathrm{W}, \mathrm{A}, \mathrm{U}$ \\
\hline & Centroptilum luteolum & GRA/DET & $\mathrm{K} 1, \mathrm{~T} 3$ & $\mathrm{~W}, \mathrm{~A}$ \\
\hline & Procloeon sp. & DET & B2, VP1 & W, A \\
\hline Caenidae & Caenis sp. & DET & $\mathrm{B} 3, \mathrm{~T} 2, \mathrm{~V} 3$ & A \\
\hline Ephemerellidae & Ephemerella sp. & GRA/DET & B1 & $\mathrm{W}$ \\
\hline Ephemeridae & Ephemera sp. & AFIL & VP2 & $\mathrm{U}$ \\
\hline Heptageniidae & Ecdyonurus sp. & GRA/DET & $\mathrm{B} 1, \mathrm{~K} 1, \mathrm{~T} 1, \mathrm{VP} 1$ & $\mathrm{~W}$ \\
\hline & Heptagenia sp. & GRA/DET & VP1 & W \\
\hline & Rhitrogena sp. & GRA & T3, VP1 & W, A \\
\hline HETEROPTERA & & & & \\
\hline Nepidae & Ranatra sp. & PRE & V2 & $\mathrm{U}$ \\
\hline ODONATA & & & & \\
\hline Aeshnidae & Aeshnidae gen. sp. & PRE & V2 & $\mathrm{U}$ \\
\hline Calopterygidae & Calopteryx sp. & PRE & V3 & $\mathrm{U}$ \\
\hline Coenagrionidae & Coenagrion sp. & PRE & $\mathrm{V} 2, \mathrm{~V} 3$ & $\mathrm{U}$ \\
\hline Cordulegastridae & Cordulegastridae gen. sp. & PRE & $\mathrm{T} 1, \mathrm{~T} 3$ & $\mathrm{~W}, \mathrm{~A}$ \\
\hline Gomphidae & Onychogomphus forcipatus & PRE & B1, T3, V3, VP2, VP3 & $\mathrm{W}, \mathrm{A}, \mathrm{U}$ \\
\hline Platycnemididae & Platycnemis pennipes & PRE & $\mathrm{V} 3$ & $\mathrm{U}$ \\
\hline PLECOPTERA & & & & \\
\hline Chloroperlidae & Chloroperla sp. & PRE & VP1 & $\mathrm{W}$ \\
\hline Perlidae & Perla sp. & PRE & B1, VP1, T1 & $\mathrm{W}$ \\
\hline TRICHOPTERA & & & & \\
\hline Hydropsychidae & Hydropsyche sp. & PFIL & B2, B3, T1, T2, T3, VP3, K1 & $\mathrm{W}, \mathrm{A}, \mathrm{U}$ \\
\hline Limnephilidae & Drusus sp. & GRA & $\mathrm{T} 1$ & $\mathrm{~W}$ \\
\hline & Limnephilidae gen. sp. & SHR & VP1 & $\mathrm{W}$ \\
\hline Rhyacophilidae & Rhyacophila sp. & PRE & $\mathrm{V} 1, \mathrm{~B} 2, \mathrm{~T} 2$ & $\mathrm{~W}, \mathrm{~A}$ \\
\hline Sericostomatidae & Sericostoma sp. & SHR & $\mathrm{B} 2$ & $\mathrm{~A}$ \\
\hline
\end{tabular}


Table S3. The isotopic variance illustrated as a size of ellipses (SEAc, $\%{ }^{2}$ ) for all potential prey (primary consumers), predators, basal resources, detritivores and grazers per each site. We only calculated the ellipses for trophic and feeding groups that included at least five samples from the same site.

\begin{tabular}{|c|c|c|c|c|c|c|}
\hline Site & & $\begin{array}{l}\text { SEAc } \\
\text { PREY }\end{array}$ & $\begin{array}{c}\text { SEAc } \\
\text { PREDATORS }\end{array}$ & $\begin{array}{c}\text { SEAc } \\
\text { RESOURCES }\end{array}$ & $\begin{array}{c}\text { SEAc } \\
\text { DETRITIVORES }\end{array}$ & $\begin{array}{c}\text { SEAc } \\
\text { GRAZERS }\end{array}$ \\
\hline & Land Use & $\left(\% 0^{2}\right)$ & $\left(\% o^{2}\right)$ & $\left(\% o^{2}\right)$ & $\left(\% o^{2}\right)$ & $\left(\% 0^{2}\right)$ \\
\hline B1 & Woodland & 5.57 & 1.25 & 9.02 & 1.70 & 1.94 \\
\hline B2 & Agricultural & 8.52 & 2.77 & 22.45 & 1.74 & 7.46 \\
\hline B3 & Agricultural & 7.00 & 1.46 & 45.14 & 7.46 & 2.42 \\
\hline VP1 & Woodland & 9.27 & 0.23 & 25.29 & 0.98 & 1.54 \\
\hline VP2 & Urban & 5.18 & 1.62 & 66.30 & 6.29 & NA \\
\hline VP3 & Urban & 3.50 & NA & 27.19 & 0.39 & 1.66 \\
\hline T1 & Woodland & 5.69 & 8.61 & 30.43 & NA & 2.09 \\
\hline $\mathbf{T} 2$ & Agricultural & 9.73 & 0.88 & 17.05 & 4.10 & NA \\
\hline T3 & Agricultural & 3.52 & 2.63 & 46.85 & 0.18 & 0.61 \\
\hline K1 & Woodland & 11.22 & NA & 57.40 & 12.80 & NA \\
\hline K2 & Urban & 108.21 & 0.61 & 60.63 & 38.91 & NA \\
\hline $\mathbf{K 3}$ & Urban & 5.14 & NA & 39.09 & 3.25 & NA \\
\hline V1 & Woodland & 5.19 & 0.14 & 42.22 & NA & 0.39 \\
\hline $\mathrm{V} 2$ & Urban & 7.45 & 5.32 & 74.31 & 9.77 & NA \\
\hline V3 & Urban & 3.40 & 1.26 & 59.43 & 3.30 & NA \\
\hline
\end{tabular}


Table S4. Trophic metrics of each food web at all 15 sites at the three land use types in the surrounding catchments. The metrics for each network are $\delta^{15} \mathrm{~N}$ range (NR), $\delta^{13} \mathrm{C}$ range (CR), total convex hull area (TA), mean distance to centroid (CD), mean distance to nearest neighbour (NND) and standard deviation of nearest neighbour distance (SDNND).

\begin{tabular}{cccccc}
\hline Site & Land Use & NR & CR & NND & SDNND \\
\hline B1 & Woodland & 3.07 & 6.76 & 0.3895269 & 0.2644774 \\
B2 & Agricultural & 8.84 & 6.53 & 0.3976789 & 0.4733168 \\
B3 & Agricultural & 5.2 & 8.26 & 0.4580102 & 0.3451934 \\
VP1 & Woodland & 4.62 & 9.6 & 0.2549206 & 0.2205836 \\
VP2 & Urban & 5.23 & 4.05 & 0.3807053 & 0.2737085 \\
VP3 & Urban & 4.81 & 2.28 & 0.453063 & 0.537001 \\
T1 & Woodland & 4.52 & 12.44 & 0.4078513 & 0.3500275 \\
T2 & Agricultural & 9.56 & 5.27 & 0.3908846 & 0.2643519 \\
T3 & Agricultural & 3.76 & 4.51 & 0.3160091 & 0.2800542 \\
K1 & Woodland & 2.67 & 16.62 & 0.4575171 & 0.3869496 \\
K2 & Urban & 15.08 & 23.28 & 0.7743367 & 0.9074948 \\
K3 & Urban & 4.49 & 3.1 & 0.6205092 & 0.4354267 \\
V1 & Woodland & 1.93 & 5.83 & 0.4245844 & 0.2662198 \\
V2 & Urban & 6.92 & 8.75 & 0.6296454 & 0.6474061 \\
V3 & Urban & 5.71 & 4.24 & 0.4890857 & 0.4229855 \\
\hline
\end{tabular}


Table S5. Results of Principal Component Analysis showing how much of the total variation can be explained by each PC axis (1-6), and the loadings of each physico-chemical parameter within each PC. Positive values and their corresponding parameters are inversely related to those with negative values.

\begin{tabular}{|c|c|c|c|c|c|c|}
\hline & $\begin{array}{c}P C 1 \\
(51.1 \%)\end{array}$ & $\begin{array}{c}P C 2 \\
(15.5 \%)\end{array}$ & $\begin{array}{c}P C 3 \\
(10.6 \%)\end{array}$ & $\begin{array}{c}P C 4 \\
(9.5 \%)\end{array}$ & $\begin{array}{c}P C 5 \\
(5.8 \%)\end{array}$ & $\begin{array}{c}P C 6 \\
(2.8 \%)\end{array}$ \\
\hline Temperature $\left({ }^{\circ} \mathrm{C}\right)$ & 0.27 & 0.35 & -0.29 & -0.46 & 0.43 & -0.22 \\
\hline $\mathrm{O}_{2}\left(\mathrm{mg} \mathrm{L}^{-1}\right)$ & 0.14 & 0.59 & 0.25 & -0.45 & -0.28 & 0.02 \\
\hline pH & 0.02 & 0.55 & 0.27 & 0.63 & 0.33 & -0.26 \\
\hline Total water hardness $\left(\mathrm{mg} \mathrm{CaCO}_{3} \mathrm{~L}^{-1}\right)$ & 0.39 & -0.17 & 0.22 & -0.16 & -0.29 & -0.17 \\
\hline Nitrite $\left(\mathbf{m g ~ L}^{-1}\right)$ & 0.42 & -0.08 & -0.13 & 0.00 & 0.18 & 0.04 \\
\hline Nitrate (mg L $\left.\mathbf{L}^{-1}\right)$ & 0.40 & -0.07 & -0.02 & 0.15 & -0.28 & -0.33 \\
\hline Orthophosphate (mg L-1) & 0.35 & -0.11 & -0.43 & 0.10 & 0.35 & 0.22 \\
\hline Conductivity $\left(\mu \mathrm{S} \mathrm{cm} \mathrm{cm}^{-1}\right)$ & 0.38 & -0.22 & 0.18 & 0.17 & -0.04 & -0.35 \\
\hline Chlorophyll a $\left(\mu \mathrm{g} \mathrm{cm}^{-2}\right)$ & 0.30 & 0.33 & -0.26 & 0.32 & -0.44 & 0.54 \\
\hline Discharge $\left(\mathrm{m}^{3} \mathrm{~s}^{-1}\right)$ & -0.26 & 0.13 & -0.66 & 0.08 & -0.35 & -0.53 \\
\hline
\end{tabular}


Table S6. Linear mixed effects model summary statistics for the effect of land use type on the mean carbon $\left(\delta^{13} \mathrm{C}\right)$ and nitrogen $\left(\delta^{15} \mathrm{~N}\right)$ stable isotope ratios for individual trophic groups. Individual sites were treated as a random effect.

\begin{tabular}{lclc}
\hline & Treatment & Statistics & P-value \\
\hline Resources & $\delta^{13} \mathrm{C}$ & $\mathrm{F}_{2,12}=3.01$ & 0.090 \\
Prey & $\delta^{13} \mathrm{C}$ & $\mathrm{F}_{2,12}=3.56$ & 0.061 \\
Predators & $\delta^{13} \mathrm{C}$ & $\mathrm{F}_{2,9}=1.89$ & 0.207 \\
Detritivores & $\delta^{13} \mathrm{C}$ & $\mathrm{F}_{2,10}=0.44$ & 0.657 \\
Grazers & $\delta^{13} \mathrm{C}$ & $\mathrm{F}_{2,12}=5.04$ & 0.026 \\
Detritivores & $\delta^{15} \mathrm{~N}$ & $\mathrm{~F}_{2,10}=6.08$ & 0.019 \\
Grazers & $\delta^{15} \mathrm{~N}$ & $\mathrm{~F}_{2,12}=9.71$ & 0.003 \\
\hline
\end{tabular}


Table S7. Linear mixed effects model summary statistics for the effect of physico-chemical site characteristics, represented by the PC2, on the low level of trophic redundancy indicated by high MNND, the uniformity of niche measures SDNND, the mean $\delta^{15} \mathrm{~N}$ and the $\delta^{15} \mathrm{~N}$ range. Individual sites were treated as a random effect.

\begin{tabular}{lcc}
\hline Treatment & Statistics & P-value \\
\hline MNND & $\mathrm{F}_{1,13}=0.12$ & 0.734 \\
SDNND & $\mathrm{F}_{1,13}=0.08$ & 0.778 \\
mean $\delta^{15} \mathrm{~N}$ & $\mathrm{~F}_{1,13}=2.31$ & 0.152 \\
$\delta^{15} \mathrm{~N}$ range & $\mathrm{F}_{1,13}=0.04$ & 0.837 \\
\hline
\end{tabular}




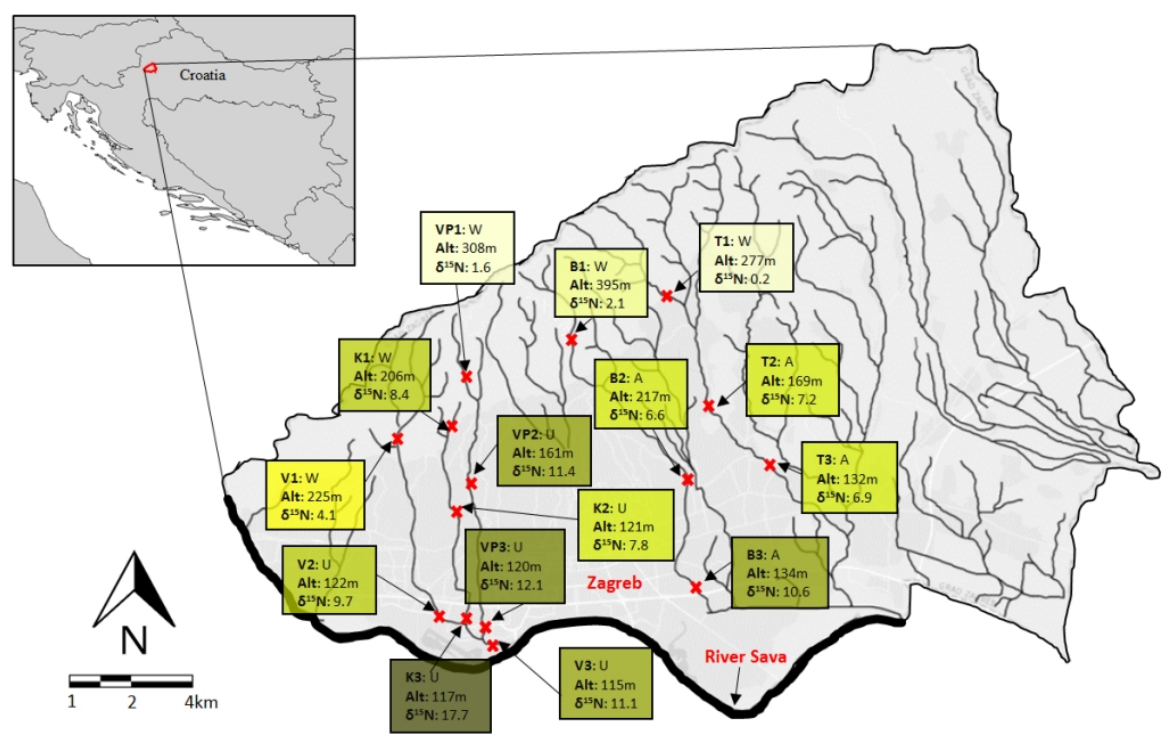

\begin{tabular}{|c|c|c|c|c|c|c|c|c|c|}
\hline Mean $\delta^{15} \mathrm{~N}$ & $0-2$ & $2-4$ & $4-6$ & $6-8$ & $8-10$ & $10-12$ & $12-14$ & $14-16$ & $16-18$ \\
\hline
\end{tabular} 